Prepared in cooperation with the Arkansas Natural Resources Commission and the Arkansas Geological Survey

\title{
Water Levels and Selected Water-Quality Conditions in the Mississippi River Valley Alluvial Aquifer in Eastern Arkansas, 2014
}

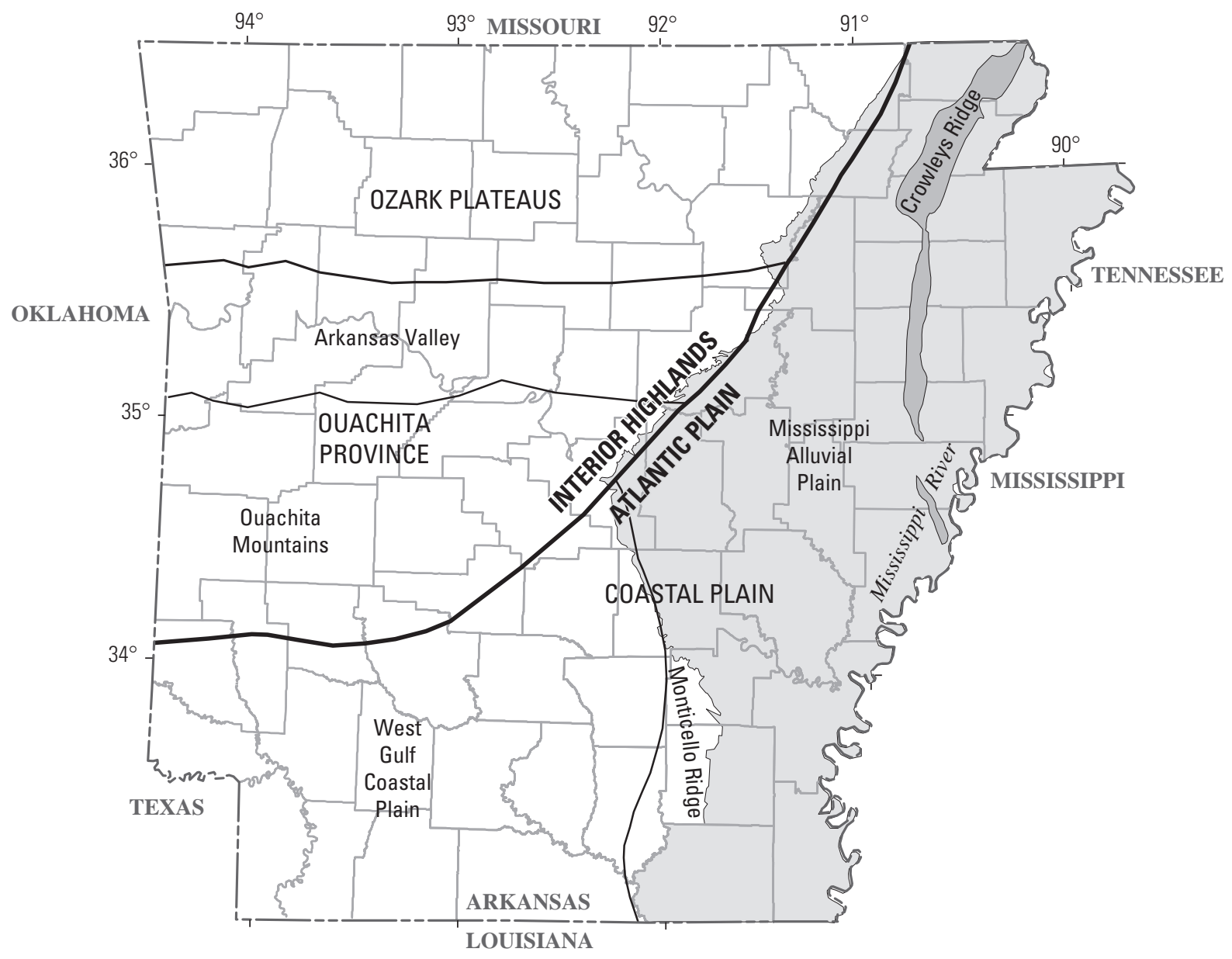

Scientific Investigations Report 2020-5123 



\section{Water Levels and Selected Water-Quality Conditions in the Mississippi River Valley Alluvial Aquifer in Eastern Arkansas, 2014}

By Kirk D. Rodgers and Amanda R. Whaling

Prepared in cooperation with the Arkansas Natural Resources Commission and the Arkansas Geological Survey

Scientific Investigations Report 2020-5123 


\title{
U.S. Department of the Interior \\ DAVID BERNHARDT, Secretary
}

\author{
U.S. Geological Survey \\ James F. Reilly II, Director
}

U.S. Geological Survey, Reston, Virginia: 2020

For more information on the USGS - the Federal source for science about the Earth, its natural and living resources, natural hazards, and the environment-visit https://www.usgs.gov or call 1-888-ASK-USGS.

For an overview of USGS information products, including maps, imagery, and publications,

visit https://store.usgs.gov.

Any use of trade, firm, or product names is for descriptive purposes only and does not imply endorsement by the U.S. Government.

Although this information product, for the most part, is in the public domain, it also may contain copyrighted materials as noted in the text. Permission to reproduce copyrighted items must be secured from the copyright owner.

Suggested citation:

Rodgers, K.D., and Whaling, A.R., 2020, Water levels and selected water-quality conditions in the Mississippi River Valley alluvial aquifer in eastern Arkansas, 2014: U.S. Geological Survey Scientific Investigations Report 2020-5123, 22 p., 3 pls., https://doi.org/10.3133/sir20205123.

Associated data for this publication:

Rodgers, K.D., 2020, Water-level data, selected water-quality data, and the potentiometric dataset for the Mississippi River Valley alluvial aquifer in eastern Arkansas, spring 2014: U.S. Geological Survey data release, https://doi. org/10.5066/F757197T.

ISSN 2328-0328 (online) 


\section{Contents}

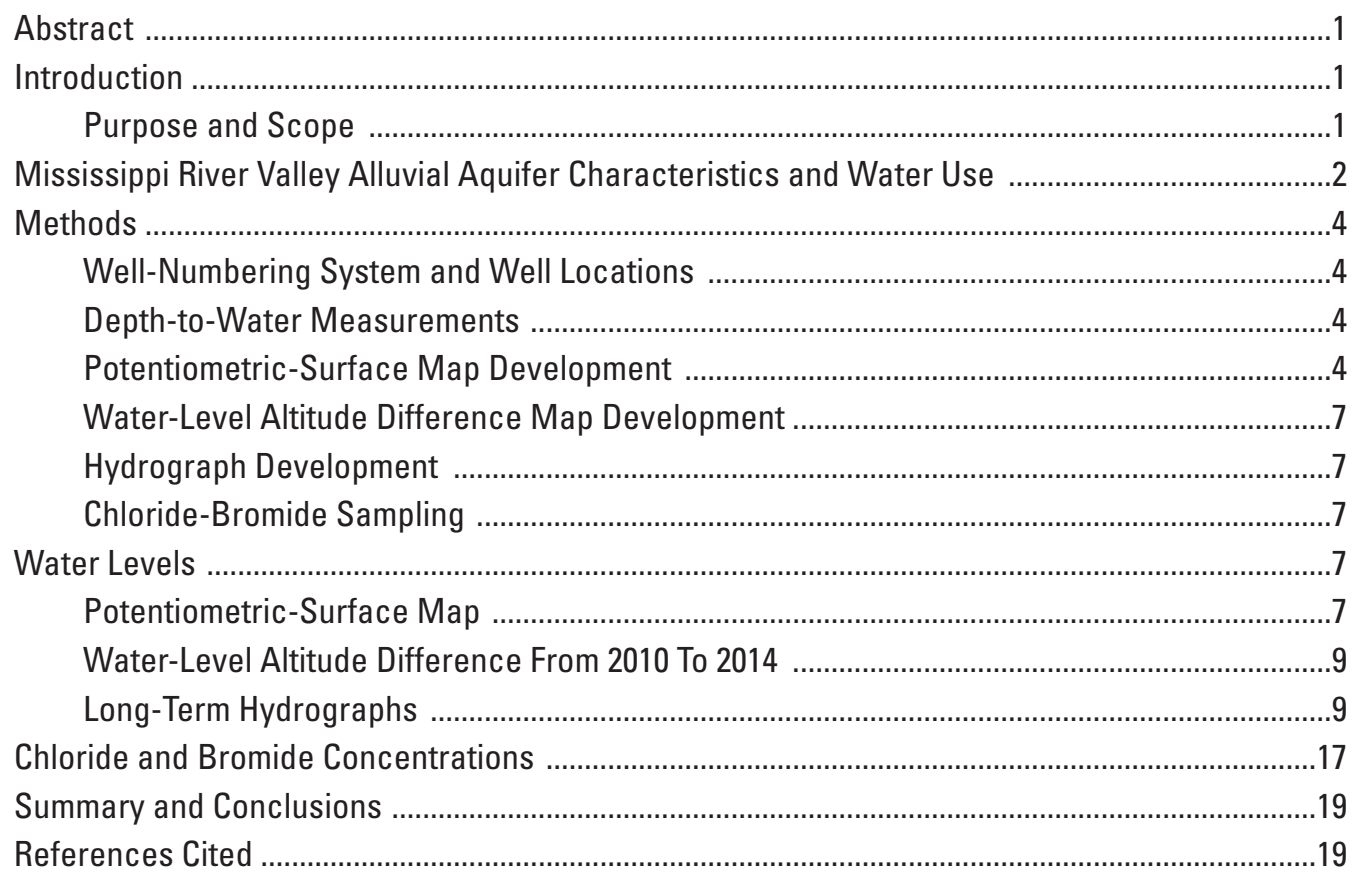

\section{Plates}

Available for downloading from https://doi.org/10.3133/sir20205123

1. Potentiometric surface of the Mississippi River Valley alluvial aquifer, spring 2014

2. Difference in water level of the Mississippi River Valley alluvial aquifer, 2010-14

3. Chloride/bromide ratio of the Mississippi River Valley alluvial aquifer, spring 2014-15

\section{Figures}

1. Map showing the location of the study area and the Mississippi embayment ...............2

2. Correlation chart showing geologic and hydrogeologic units of the Mississippi River Valley alluvial aquifer and the Mississippi embayment aquifer system ..................3

3. Graph showing water withdrawals from the Mississippi River Valley alluvial aquifer in Arkansas, 1965-2010 . .4

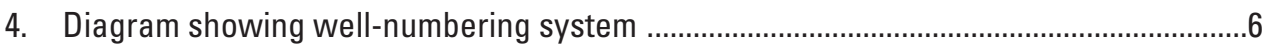

5. Water-level altitude hydrographs for selected wells completed in the Mississippi River Valley alluvial aquifer in Arkansas

6. Graph showing distribution of chloride/bromide ratios in samples from the Mississippi River Valley alluvial aquifer in Arkansas, 2014 


\section{Tables}

1. Water withdrawals by county, from wells completed in the Mississippi River Valley alluvial aquifer in Arkansas, 1960-2010

2. Summary statistics for water-level altitudes, by county, in selected wells in the Mississippi River Valley alluvial aquifer, 2014

3. Summary statistics for water-level altitude differences, by county, in selected wells in the Mississippi River Valley alluvial aquifer

4. Range, mean, and median of annual year-to-year difference in water level, by county, for wells in the Mississippi River Valley alluvial aquifer, 1990-2014

5. Summary statistics for chloride/bromide ratios by county in samples from selected wells in the Mississippi River Valley alluvial aquifer, 2014 


\section{Conversion Factors}

U.S. customary units to International System of Units

\begin{tabular}{|c|c|c|}
\hline Multiply & By & To obtain \\
\hline \multicolumn{3}{|c|}{ Length } \\
\hline foot $(\mathrm{ft})$ & 0.3048 & meter (m) \\
\hline \multicolumn{3}{|c|}{ Area } \\
\hline square mile $\left(\mathrm{mi}^{2}\right)$ & 2.590 & square kilometer $\left(\mathrm{km}^{2}\right)$ \\
\hline \multicolumn{3}{|c|}{ Flow rate } \\
\hline foot per year (ft/yr) & 0.3048 & meter per year (m/yr) \\
\hline gallon per minute (gal/min) & 0.06309 & liter per second (L/s) \\
\hline million gallons per day (Mgal/d) & 0.04381 & cubic meter per second $\left(\mathrm{m}^{3} / \mathrm{s}\right)$ \\
\hline
\end{tabular}

Temperature in degrees Celsius $\left({ }^{\circ} \mathrm{C}\right)$ may be converted to degrees Fahrenheit $\left({ }^{\circ} \mathrm{F}\right)$ as ${ }^{\circ} \mathrm{F}=\left(1.8 \times{ }^{\circ} \mathrm{C}\right)+32$

\section{Datums}

Vertical coordinate information is referenced to the National Geodetic Vertical Datum of 1929 (NGVD 29).

Horizontal coordinate information is referenced to North American Datum of 1983 (NAD 83).

Altitude, as used in this report, refers to distance above the vertical datum.

\section{Supplemental Information}

Concentrations of chemical constituents in water are given in milligrams per liter (mg/L).

\section{Abbreviations}

ANRC Arkansas Natural Resources Commission

NRCS Natural Resources Conservation Service

NWIS National Water Information System

PAEK Polynomial Approximation with Exponential Kernel

USGS U.S. Geological Survey 



\title{
Water Levels and Selected Water-Quality Conditions in the Mississippi River Valley Alluvial Aquifer in Eastern Arkansas, 2014
}

\author{
By Kirk D. Rodgers and Amanda R. Whaling
}

\section{Abstract}

In 2014, the U.S. Geological Survey, in cooperation with the Arkansas Geological Survey and the Arkansas Natural Resources Commission, determined water-level altitudes in 468 wells in eastern Arkansas and collected water-quality samples from 144 wells. Water-level altitudes were calculated based on the measured depth to water in each well and used to construct a potentiometric-surface map of the Mississippi River Valley alluvial aquifer, and the water-quality samples were analyzed for chloride and bromide concentrations. Upon completion of the potentiometric-surface map, 10 depressions in the potentiometric surface were identified in the Mississippi Alluvial Plain: two large depressions, five small depressions, and three areas of decreased water levels. Analyses of waterquality samples identified several areas of elevated chloride/ bromide ratios.

A water-level altitude difference map was constructed using 345 groundwater levels measured in 2010 and 2014. Differences in water-level altitude ranged from -10.2 feet in Craighead County to 18.00 feet in Prairie County. Analysis of the overall water-level altitude differences indicated a decline in approximately 84 percent of the wells measured in both 2010 and 2014, including in areas where previous studies indicated water-level altitude increases between 2008 and 2012. Analysis of long-term hydrographs of wells in the study area indicated that mean annual water levels declined in all but two counties. The decline in water levels observed in the hydrographs suggests continued growth of the cones of depression caused by groundwater use in the Mississippi River Valley alluvial aquifer.

\section{Introduction}

The Mississippi River Valley alluvial aquifer (herein referred to as the alluvial aquifer) is an important natural resource in Arkansas that provides water for extensive irrigation to support agricultural production in the eastern part of the State. Depth to water is monitored and measured across eastern Arkansas to evaluate and map continued declining trends in water-level altitude and flow directions in the alluvial aquifer. Water-level altitudes can be used to develop a potentiometric-surface map that represents the altitude at which water would stand in tightly cased wells at any location within the aquifer (Lohman, 1972). The direction of groundwater flow from areas of higher to lower altitude can be inferred using the potentiometric-surface map, and areas of decreased groundwater levels can be identified. The preparation of potentiometric-surface maps through time provides decision makers with information describing temporal changes in water-level altitude and can aid in determining areas of increased water use.

During the spring of 2014, the U.S. Geological Survey (USGS), in cooperation with the Arkansas Geological Survey and the Arkansas Natural Resources Commission (ANRC), initiated a study to map the potentiometric surface, assess the difference in water-level altitudes between 2010 and 2014, and analyze long-term groundwater trends, including chloride and bromide concentrations and water-level altitudes of the alluvial aquifer. The analyses provided information that can be used to identify areas that have potential water-quality issues and to evaluate trends in water-quality changes. In addition, the water-level altitude data inform water resource managers by identifying areas where water-level altitudes are declining and water availability is potentially decreasing over time. Collectively, the results of this investigation provide Federal, State, and local agencies with the information needed to better define the water availability of the alluvial aquifer and to understand and manage local water resources (Evenson and others, 2013).

\section{Purpose and Scope}

The purpose of the report is to describe the results of measured depths to water in wells completed in the alluvial aquifer and to compare those results with previous measurements to identify the direction of groundwater flow, areas of depressed water-level altitudes and long-term trends for water-level altitudes in the alluvial aquifer. Information in this report includes (1) water-level altitudes for spring 2014, (2) a potentiometric-surface map, (3) a water-level altitude difference map comparing water levels from 2010 and 2014, (4) selected long-term water-level hydrographs, 
(5) a chloride-bromide ratio map, and (6) water-quality data collected from the alluvial aquifer during the summer of 2014. All depth-to-water measurements are publicly available online from the USGS National Water Information System database (NWIS; U.S. Geological Survey, 2016). The water-level altitude data, water-level altitude differences data, the chloride and bromide data, and the potentiometric dataset that support the findings in this report are available from Rodgers (2020).

\section{Mississippi River Valley Alluvial Aquifer Characteristics and Water Use}

The Mississippi embayment spans an area of approximately 160,000 square miles (Cushing and others, 1964; Williamson and others, 1990; Arthur and Taylor, 1998), extending across parts of Alabama, Arkansas, Illinois, Kentucky, Louisiana, Mississippi, Missouri, and Tennessee (fig. 1). The alluvial aquifer of the Mississippi embayment lies within a syncline plunging southward toward the Gulf of Mexico, with the axis of the syncline roughly following the Mississippi River (Cushing and others, 1964; Hart and others, 2008). The trough of the syncline is composed of deposits of Cretaceous to Quaternary age (Ackerman, 1996).
The unconsolidated sediments of the alluvial aquifer grade from silt and clay in the upper sections, which act as a confining unit over much of the aquifer, to gravel and coarse sand in lower sections (Boswell and others, 1968), which are capable of sustaining high-yielding wells (Ackerman, 1996). Channel-fill, point bar, and backswamp deposits associated with present or former channels of large rivers have created abrupt changes in lithology and result in large spatial variations in hydraulic properties of the aquifer (Joseph, 1999). Tertiary age or older sedimentary rocks and unconsolidated sediments that underlie the alluvial aquifer have been altered by geologic processes to form an undulating surface (Mahon and Poynter, 1993). The Tertiary and Cretaceous rocks and sediments are less permeable in most areas than the overlying alluvial and terrace deposits of Quaternary age and form distinct aquifers and confining units below the alluvial aquifer (fig. 2; Boswell and others, 1968). According to Kresse and others (2014), virtually all of the landforms and associated sediments within the Mississippi River Valley are the direct result of fluvial process. The dominant controls influencing the fluvial processes and resulting surficial geology include glaciation, climate, relative sea level, tectonism, and subsidence (Saucier, 1994). In the northern part of the study area, the alluvial aquifer occupies a vast, low, flat alluvial plain containing one major feature,

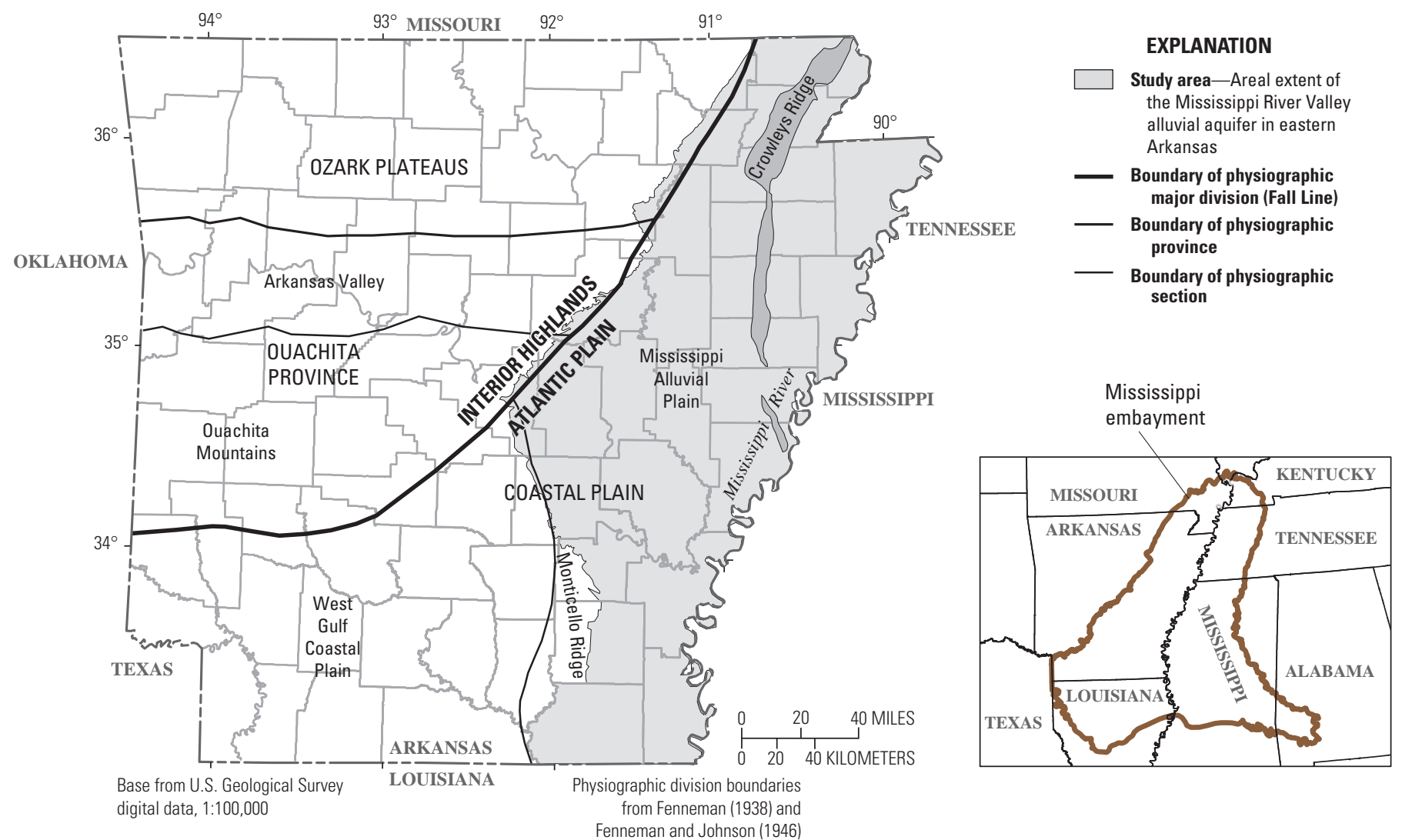

Figure 1. The location of the study area and the Mississippi embayment. 


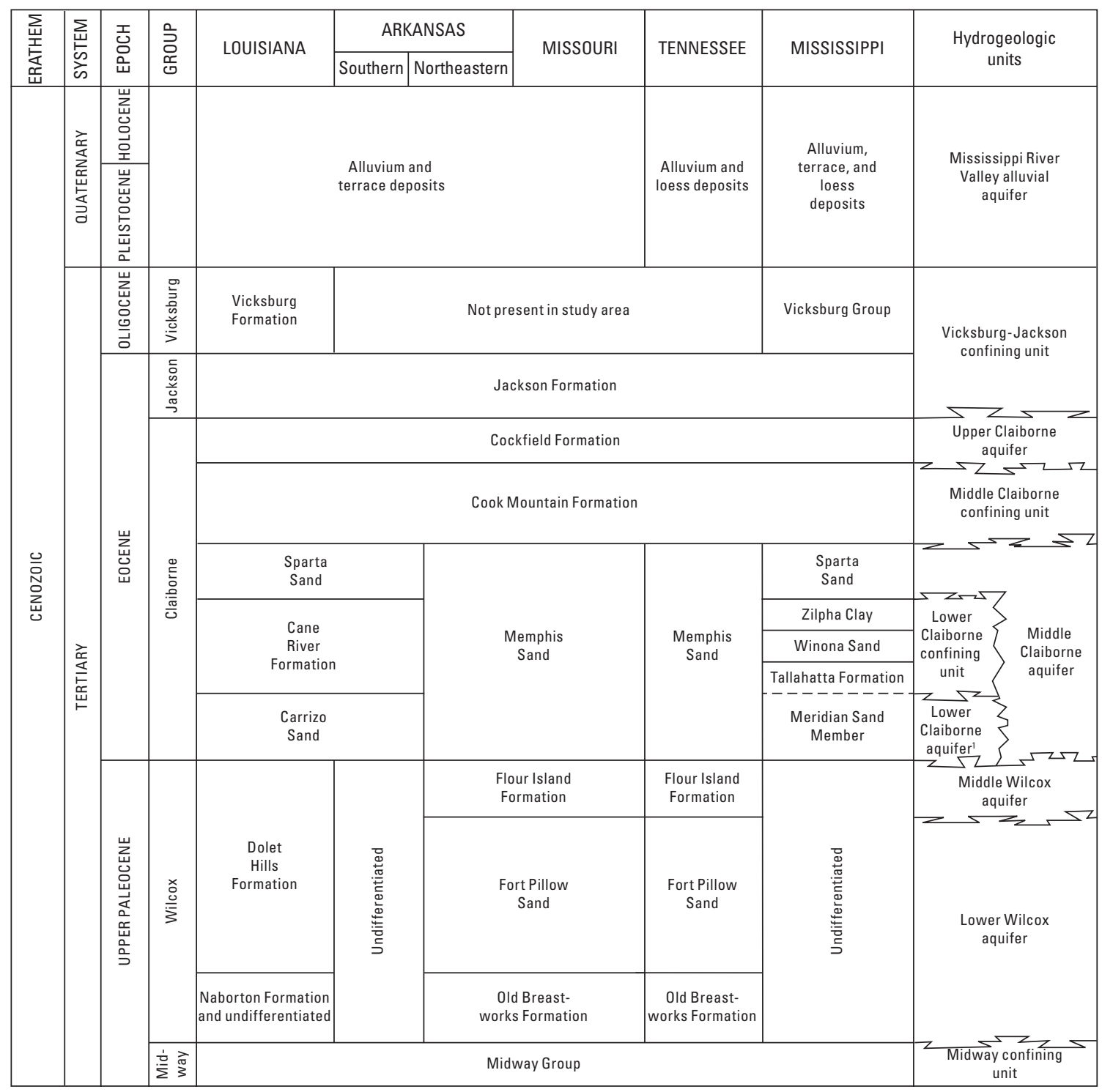

Figure 2. Correlation chart showing geologic and hydrogeologic units of the Mississippi River Valley alluvial aquifer and the Mississippi embayment aquifer system (modified from Clark and others, 2011).

Crowleys Ridge (Ackerman, 1996). The ridge is a north-south trending erosional remnant of Tertiary-age strata that bisect the northern half of the alluvial plain and control regional groundwater flow patterns (Ackerman, 1996).

The Mississippi Alluvial Plain spans approximately 32,000 square miles and includes parts of seven States, namely Arkansas, Illinois, Kentucky, Louisiana, Mississippi, Missouri, and Tennessee. Approximately 54 percent of the Mississippi Alluvial Plain is located in the eastern third of Arkansas (fig. 1; Pugh and others, 1997). The alluvial aquifer underlies the Mississippi Alluvial Plain, and in Arkansas, for the purpose of this study, extends southward from the Missouri State line to the Louisiana State line, and westward from the Mississippi River to (1) Monticello Ridge in southeastern Arkansas and (2) the Fall Line, between the Atlantic Plain and Interior Highlands, in central and northeastern Arkansas (fig. 1; Schrader, 2008).

Water use in the alluvial aquifer increased tenfold between 1960 and 2010 (fig. 3). According to Pugh and Holland (2015), agriculture and aquaculture account for the largest percentage of water used. Water withdrawal estimates from the alluvial aquifer in Arkansas have increased from approximately 900 million gallons per day in 1965 (Halberg and Stephens, 1966), to approximately 7,400 million gallons per day in 2010 (Pugh and Holland, 2015), an overall increase of over 700 percent (fig. 3). From 1985 to 2010, withdrawals more than doubled, an increase of 127 percent (Schrader, 2015). The percent change over the period of record (1960-2010) for counties of the alluvial aquifer range from 235 percent in Lonoke County to 10,371 percent in Mississippi County (table 1; Pugh and Holland, 2015). 


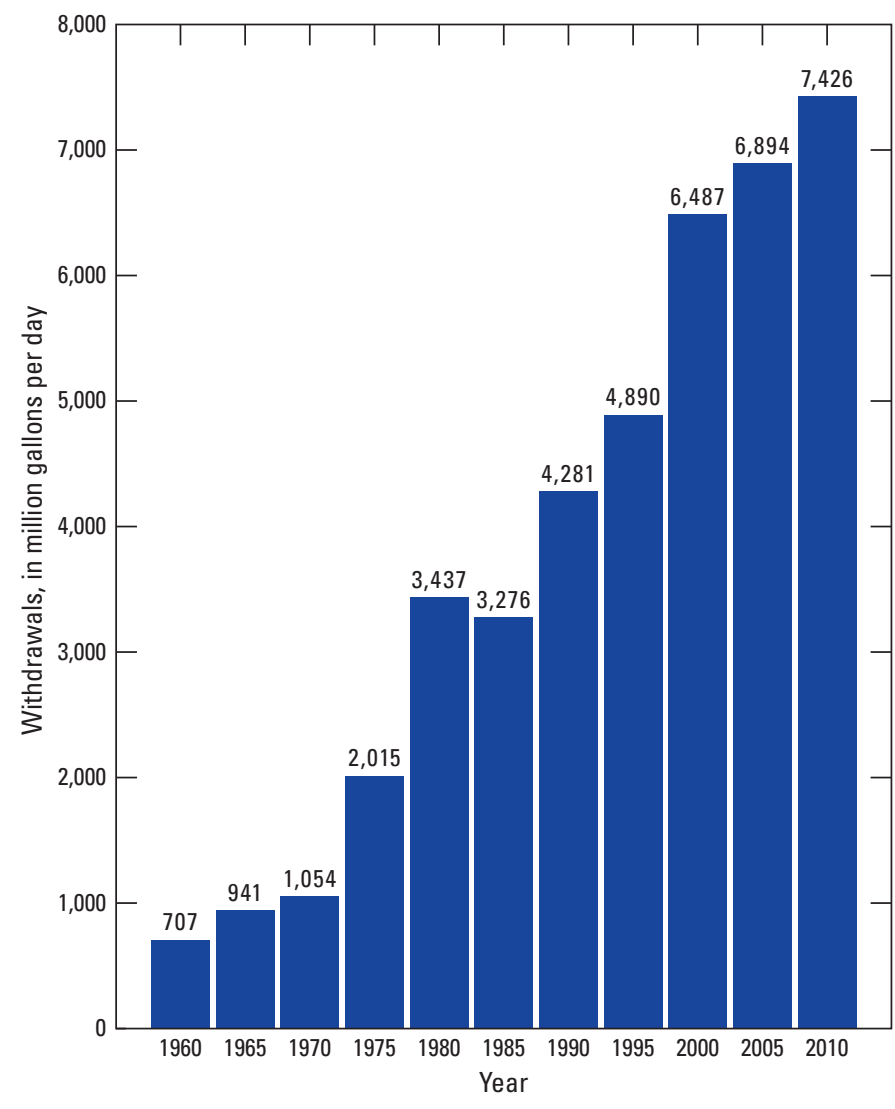

Figure 3. Water withdrawals from the Mississippi River Valley alluvial aquifer in Arkansas, 1965-2010. Data compiled from Halberg and Stephens (1966); Halberg (1972, 1977); Holland and Ludwig (1981); Holland (1987, 1993, 1999, 2004, 2007); and Pugh and Holland (2015).

\section{Methods}

\section{Well-Numbering System and Well Locations}

The well-numbering system used in this report is based upon the location of the wells according to the Public Land Survey System. The component parts of a well number are the township number and direction; the range number and direction; the section number; and three letters that indicate, respectively, the quarter section, quarter-quarter section, the quarter-quarter-quarter section in which the well is located, and a sequence number of the well in the quarter-quarterquarter section. The letters are assigned counterclockwise, beginning with "A" in the northeast quarter, quarter-quarter or quarter-quarter-quarter section. For example, well 01S03W04BBD16 (fig. 4) is located in Township 1 South, Range 3 West, Section 4, and then in the southeast quarter of the northwest quarter of the northwest quarter of section 4 . This well is the 16th well in the quarter-quarter-quarter section of section 4 from which data were collected.
Well locations listed in the USGS National Water Information System database (NWIS) were determined using Global Positioning System receivers to acquire the horizontal coordinate information (latitude and longitude) based upon the North American Datum of 1983 (NAD 83). Land-surface altitude, measured in feet above the National Geodetic Vertical Datum of 1929 (NGVD 29), was determined for each well by superposition of the latitude and longitude of the well on a USGS topographic map and is accurate to about one-half the topographic contour interval of 5 to 10 feet (ft). Herein, all water-level and land-surface altitudes are referenced to NGVD 29.

\section{Depth-to-Water Measurements}

Depth to water in each well was measured by USGS, ANRC, and Natural Resources Conservation Service (NRCS) personnel during 2014 in wells completed in the alluvial aquifer. Measurements were made with electric or steel tapes graduated to hundredths of a foot. The tapes were calibrated during January 2014 prior to data collection. Calibration of electric and steel tapes was performed by comparing the tapes to a standardized steel tape used for calibration only (Cunningham and Schalk, 2011).

\section{Potentiometric-Surface Map Development}

The potentiometric-surface map created for the alluvial aquifer in eastern Arkansas documented in this report was constructed using water-level altitudes for 468 wells completed in the alluvial aquifer ( 6 measurements by the ANRC, 157 by the NRCS, and 305 by the USGS) collected during spring 2014 and retrieved from the NWIS database (U.S. Geological Survey, 2016). Water-level altitudes were calculated by subtracting the depth-to-water measurement from the land-surface altitude, rounded to the nearest foot, and referenced to NGVD 29. Arrows were added to the potentiometric-surface map to indicate flow direction toward the lowest water-level altitude in an area or areas of the aquifer.

The longitude and latitude of individual wells were obtained from NWIS and encoded using ArcGIS (Esri, 2011). The encoded data points were used to compile a potentiometricsurface map of the alluvial aquifer by interpolation. This process produces a raster image that assigns a range of values to each color in the image. The image is then converted to contour polylines using the raster-to-contour tool. Upon conversion, the contour polylines were corrected and refined using the Polynomial Approximation with Exponential Kernel (PAEK) method of smoothing, which allows for the preservation of endpoints. This algorithm uses the maximum allowable offset to smooth lines (Bodansky and others, 2002) and sets a tolerance by which lines are smoothed. A higher tolerance preserves less detail from the original interpolated contour line, and a lower tolerance preserves more detail. A 0.2-decimal-degree tolerance was used to smooth the contour lines and to preserve sufficient detail from the original potentiometric contour polylines. 
Table 1. Water withdrawals by county, from wells completed in the Mississippi River Valley alluvial aquifer in Arkansas, 1960-2010.

[Data from Pugh and Holland (2015). Withdrawals are in million gallons per day. --, data not available]

\begin{tabular}{|c|c|c|c|c|c|c|c|c|c|c|c|c|c|}
\hline County & 1960 & 1965 & 1970 & 1975 & 1980 & 1982 & 1985 & 1990 & 1995 & 2000 & 2005 & 2010 & $\begin{array}{c}\text { Percent } \\
\text { change } \\
\text { between } \\
1960 \text { and } 2010\end{array}$ \\
\hline Ashley & 10 & 14 & 18 & 35 & 89 & 75 & 61 & 67 & 69 & 98 & 125 & 120 & 1,120 \\
\hline Chicot & 13 & 12 & 20 & 42 & 64 & 68 & 72 & 107 & 121 & 128 & 191 & 155 & 1,057 \\
\hline Clay & 18 & 20 & 18 & 59 & 148 & 142 & 174 & 195 & 170 & 263 & 466 & 370 & 1,986 \\
\hline Cross & 53 & 67 & 80 & 165 & 220 & 274 & 255 & 335 & 281 & 409 & 596 & 519 & 872 \\
\hline Desha & 24 & 39 & 69 & 114 & 131 & 103 & 106 & 207 & 217 & 311 & 284 & 355 & 1,356 \\
\hline Drew & 6 & 7 & 14 & 23 & 44 & 44 & 40 & 36 & 55 & 51 & 74 & 82 & 1,197 \\
\hline Greene & 8 & 13 & 12 & 2 & 132 & 79 & 124 & 106 & 147 & 155 & 206 & 339 & 4,205 \\
\hline Independence & 2 & 2 & 4 & 7 & 17 & 23 & 32 & 8 & 17 & 34 & 40 & 56 & 3,631 \\
\hline Jackson & 53 & 49 & 51 & 154 & 207 & 211 & 198 & 266 & 275 & 361 & 370 & 415 & 690 \\
\hline Lincoln & 17 & 24 & 52 & 71 & 87 & 90 & 85 & 108 & 128 & 167 & 178 & 195 & 1,032 \\
\hline Lonoke & 92 & 101 & 104 & 159 & 247 & 198 & 201 & 233 & 234 & 334 & 356 & 309 & 235 \\
\hline Mississippi & 3 & 4 & 4 & 5 & 30 & 28 & 48 & 98 & 132 & 178 & 271 & 362 & 10,371 \\
\hline Monroe & 31 & 52 & 39 & 74 & 126 & 117 & 114 & 174 & 178 & 234 & 270 & 262 & 743 \\
\hline Phillips & 14 & 13 & 12 & 15 & 77 & 66 & 72 & 115 & 132 & 198 & 204 & 260 & 1,759 \\
\hline Poinsett & 52 & 85 & 98 & 176 & 303 & 335 & 297 & 395 & 431 & 582 & 671 & 837 & 1,500 \\
\hline Prairie & 52 & 68 & 56 & 120 & 157 & 149 & 147 & 194 & 191 & 227 & 219 & 208 & 303 \\
\hline Pulaski & 5 & 6 & 8 & 14 & 23 & 21 & 22 & 18 & 14 & 20 & 21 & 20 & 273 \\
\hline Randolph & 3 & 3 & 3 & 18 & 42 & 43 & 41 & 51 & 59 & 85 & 101 & 111 & 3,399 \\
\hline St. Francis & 37 & 30 & 46 & 99 & 137 & 131 & 107 & 156 & 182 & 246 & 285 & 336 & 798 \\
\hline White & 1 & 2 & 2 & 11 & 49 & 44 & 47 & 39 & 56 & 46 & 42 & 32 & 2,142 \\
\hline Woodruff & 31 & 52 & 41 & 114 & 166 & 158 & 141 & 139 & 247 & 347 & 263 & 212 & 593 \\
\hline
\end{tabular}




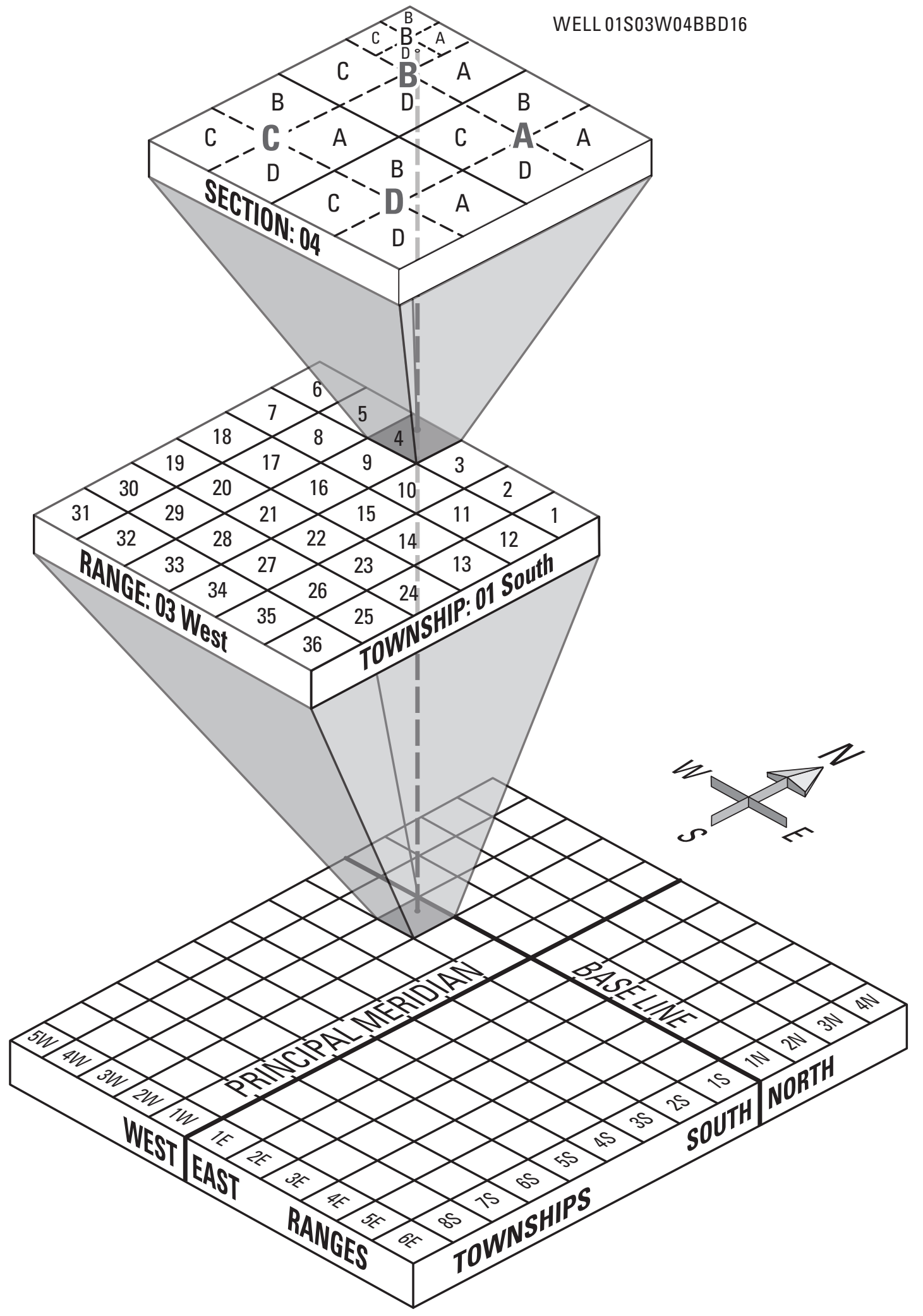

Figure 4. Diagram showing well-numbering system. 


\section{Water-Level Altitude Difference Map Development}

A water-level altitude difference map for the alluvial aquifer in eastern Arkansas was compiled to spatially evaluate short-term (4-year) changes in water levels. The map was compiled using differences between water-level altitudes determined from measurements made by the ANRC, NRCS, and USGS in 2010 and 2014 at 345 wells screened in the alluvial aquifer. Positive values indicate rises in water levels and negative values indicate declines in water levels.

\section{Hydrograph Development}

Long-term water-level altitude changes were evaluated using 14 hydrographs in the alluvial aquifer with a period of record from 1989 to 2014. Changes shown in hydrographs are typically indicative of the development of the cones of depression seen in potentiometric-surface maps. Linear regression analysis was used to determine the annual rise or decline of water-level altitudes in selected wells using the well hydrograph. Depth to water measurements in wells, made yearly during February, March, and April, with a minimum 25-year period of record were used in the linear regression analysis. A 25-year minimum period of analysis reduces the effect of localized short-term pumping rates and variations in climate on water levels in a given well. The equation of the regression line or line of best fit is $y=m x+b$. The slope, $m$, from the equation, represents the daily rise (positive value) or decline (negative value) in water-level altitude; $b$ is the waterlevel altitude, in feet, where the line intersects the $y$-axis; $\mathrm{x}$ is time, in years; and $\mathrm{y}$ is the water-level altitude, in feet above NGVD 29. Five assumptions are associated with linear regression: (1) y is linearly related to $\mathrm{X}$, (2) data used to fit the linear regression are representative of the data of interest, (3) variance of the residuals is constant and does not depend on X or on anything else, (4) the residuals are independent, and (5) the residuals are normally distributed (required for hypotheses testing as described by Helsel and Hirsch, 1992).

\section{Chloride-Bromide Sampling}

Well-casing diameter, depth-to-water, and well depth were used to calculate casing volumes for the sampled wells (Schrader, 2015). The casing diameter was used to calculate the cross-sectional area of the well casing and screen. Subtracting the depth-to-water from the well depth enabled the calculation of the height of the water column (Schrader, 2015). The casing volume, in cubic feet, was calculated by multiplying the cross-sectional area by the height of the water column and then converting to gallons (Schrader, 2015). The calculated purge volume at each well was then divided by the pumping rate to determine the minimum pumping time for purging (Schrader, 2015). Prior to collection of water-quality samples, wells were purged at a minimum of three-casing volumes at pumping rates between 100 to 500 gallons per minute in order to obtain water-quality samples representative of the aquifer conditions, thereby minimizing the effect of the borehole environment (Schrader, 2015). Temperature and $\mathrm{pH}$ were measured during the purging process to verify that aquifer conditions had stabilized prior to collection of the water-quality sample.

During the summer of 2014, groundwater samples were collected from 144 wells completed in the alluvial aquifer. Onsite, field samples were measured for $\mathrm{pH}$ and temperature using probes calibrated twice daily during the sampling season. Water-quality samples were collected according to procedures described in the USGS National Field Manual for the Collection of Water-Quality Data (U.S. Geological Survey, variously dated) and were sent to the USGS National Water Quality Laboratory in Lakewood, Colorado, for determination of chloride and bromide concentrations in milligrams per liter. The samples were analyzed for chloride and bromide using procedures described by Fishman and Friedman (1989) and are publicly available in NWIS (USGS, 2016). The chloride/ bromide ratio at each of the 144 wells was expressed as a ratio of the concentration of each element.

\section{Water Levels}

\section{Potentiometric-Surface Map}

The potentiometric-surface map of the alluvial aquifer for 2014 in eastern Arkansas shows areas where the groundwater is regionally affected by withdrawals (pl. 1). East of Crowleys Ridge in the northern part of the study area, groundwater flows toward the southwest. In southeastern Jackson County, groundwater flows toward a cone of depression and away from the White River. In Phillips County, the primary direction of groundwater flow is southwest toward the White River. Groundwater in Lonoke, Prairie, and Arkansas Counties flows toward the cone of depression in the central part of the study area. Groundwater in Greene, Phillips, Ashley, Crittendon, and St. Francis Counties flows toward small cones of depression located in each county. In Chicot, Desha, and Drew Counties, groundwater flows toward areas of decreased groundwater levels in the northwest corner of Chicot County. In Chicot and Ashley Counties, groundwater flows toward an area of decreased water-level altitude on the border between the two counties.

Groundwater flow in relation to the Arkansas and White Rivers varies according to location (pl. 1). Along the lower reaches of both rivers, groundwater flow is variable. In the upstream reaches of both rivers, groundwater flow is generally away from the river. Along the lower reaches of both rivers, the groundwater flow seems to be minimally affected by the rivers, with groundwater flowing toward and away from them. Near the Mississippi River, groundwater flows parallel to the river. 
Water-level altitudes determined during spring 2014 in the alluvial aquifer ranged from an altitude of $70 \mathrm{ft}$ NGVD 29 in Ashley County to $280 \mathrm{ft}$ NGVD 29 in Clay County (table 2). The potentiometric-surface map shows 10 total depressions: two large cones of depression, five small depressions, and three areas of decreased water levels (pl. 1). As with the 2010 potentiometric-surface map, one large depression extends to the northwest from southeastern Arkansas County, near the Arkansas and Desha County line, into Prairie and Lonoke Counties and includes a small part of southwestern Monroe County (Schrader, 2015). Even though the center of the cone of depression had deepened in 2010 (Schrader, 2015), the area within the southeastern half of the cone had not expanded horizontally between 2010 and 2012 (Schrader, 2015). The analysis of the 2014 potentiometric-surface map shows no further horizontal expansion of this cone. Within this larger cone of depression, two areas of decreasing water levels are present in Arkansas and Lonoke Counties. The two areas are separated by a ridge of slightly higher water-level altitudes. In the southern part of this cone of depression, the lowest waterlevel altitude was $81 \mathrm{ft}$ (table 2) in Arkansas County well 05S03W09CBA1 and in the northern part of the depression, a well in Lonoke County (well 01N07W27AAD1) had a waterlevel altitude of $84 \mathrm{ft}$ (table 2).

In the southern part of the large cone of depression west of Crowleys Ridge, the lowest water-level altitude was $130 \mathrm{ft}$ in Monroe County well 01N01W15DBC1 and in Woodruff County well 05N01W13CDC1 (table 2). In the northern part

Table 2. Summary statistics for water-level altitudes, by county, in selected wells in the Mississippi River Valley alluvial aquifer, 2014.

[All water-level altitudes are referenced to the National Geodetic Vertical Datum of 1929 (NGVD 29). --, data not available]

\begin{tabular}{|c|c|c|c|c|c|}
\hline County & $\begin{array}{c}\text { Minimum } \\
\text { water-level } \\
\text { altitude (feet) }\end{array}$ & $\begin{array}{c}\text { Maximum } \\
\text { water-level } \\
\text { altitude (feet) }\end{array}$ & $\begin{array}{c}\text { Median } \\
\text { water-level } \\
\text { altitude (feet) }\end{array}$ & $\begin{array}{c}\text { Mean } \\
\text { water-level } \\
\text { altitude (feet) }\end{array}$ & $\begin{array}{l}\text { Number } \\
\text { of wells }\end{array}$ \\
\hline Arkansas & 81 & 183 & 120.0 & 121.2 & 33 \\
\hline Ashley & 70 & 206 & 90.0 & 96.5 & 19 \\
\hline Chicot & 79 & 101 & 89.0 & 89.7 & 14 \\
\hline Clay & 250 & 280 & 269.0 & 263.7 & 9 \\
\hline Craighead & 133 & 225 & 208.0 & 201.1 & 31 \\
\hline Crittenden & 168 & 204 & 185.0 & 186.4 & 21 \\
\hline Cross & 128 & 189 & 143.0 & 149.5 & 42 \\
\hline Desha & 84 & 128 & 115.0 & 112.3 & 18 \\
\hline Drew & 88 & 146 & 115.0 & 118.2 & 9 \\
\hline Greene & 192 & 264 & 231.0 & 232.4 & 27 \\
\hline Independence & 212 & 228 & 216.0 & 218.7 & 3 \\
\hline Jackson & 151 & 226 & 199.0 & 196.0 & 15 \\
\hline Jefferson & 156 & 201 & 183.0 & 179.5 & 13 \\
\hline Lawrence & 194 & 242 & 221.5 & 218.8 & 8 \\
\hline Lee & 132 & 180 & 154.0 & 154.6 & 14 \\
\hline Lincoln & 117 & 169 & 137.0 & 140.3 & 15 \\
\hline Lonoke & 84 & 229 & 136.0 & 139.1 & 39 \\
\hline Mississippi & 198 & 244 & 223.5 & 222.3 & 10 \\
\hline Monroe & 130 & 174 & 153.0 & 148.9 & 24 \\
\hline Phillips & 134 & 175 & 159.5 & 158.8 & 8 \\
\hline Poinsett & 115 & 214 & 140.0 & 154.8 & 19 \\
\hline Prairie & 99 & 172 & 126.0 & 129.7 & 23 \\
\hline Pulaski & -- & -- & -- & -- & -- \\
\hline Randolph & 231 & 271 & 256.0 & 253.5 & 4 \\
\hline St. Francis & 133 & 174 & 147.0 & 149.2 & 15 \\
\hline White & 152 & 222 & 199.0 & 197.5 & 11 \\
\hline Woodruff & 130 & 204 & 182.5 & 176.3 & 24 \\
\hline
\end{tabular}


of this same cone of depression, the lowest water-level altitude was $115 \mathrm{ft}$ in Poinsett County well 11N02E26AAB1 (table 2; pl. 1). As with the cone of depression in the central part of the study area, two distinct areas of decreased water-level altitude are present, indicating increased water usage in these areas. The expansion and merging of two cones of depression in 2002 (Reed, 2004) supports the inference of increased usage in these two areas.

In southeastern Greene County, a small cone of depression exists where a groundwater level of $192 \mathrm{ft}$ was measured (table 2; pl. 1). This depression has deepened since 1998, when a previous potentiometric-surface map (Joseph, 1999) indicated a groundwater altitude of $214 \mathrm{ft}$. Another small cone of depression west of Crowleys Ridge in St. Francis County has a measured water level of $143 \mathrm{ft}$ and has merged with the larger cone of depression previously noted. In Ashley and Phillips counties, small cones of depression having measured groundwater levels of $95 \mathrm{ft}$ and $149 \mathrm{ft}$, respectively, indicate areas of high groundwater usage and a small cone of depression (173 ft) in northern Crittenden County exists that was not shown in previous reports. Three areas of decreased water levels exist at the Ashley County-Chicot County border, in northern Chicot and southern Desha Counties, and in northern Desha County. The existence of these cones of depression and areas of decreased groundwater levels suggest long-term change in the hydrologic conditions of the alluvial aquifer (Schrader, 2015).

\section{Water-Level Altitude Difference From 2010 To 2014}

The difference in water-level altitudes from 2010 to 2014 ranged from $-10.2 \mathrm{ft}$ in Craighead County to $18.0 \mathrm{ft}$ in Prairie County (pl. 2, table 3), with a mean of $-2.68 \mathrm{ft}$. Overall, water-level altitudes declined throughout the study area; approximately 84 percent of the water-level altitude differences calculated were negative. Areas described by Schrader (2015) continue to show declines in water levels, including (1) the area west of Crowleys Ridge from Greene County south to Lee County, which includes eastern Lawrence and southern Woodruff Counties; (2) the area east of Crowleys Ridge in Craighead, Mississippi and Poinsett Counties; (3) Lonoke County and part of Jefferson County; and (4) northern and eastern Desha, Drew, Chicot, and Ashley Counties. Two areas that previously indicated rising waterlevel altitudes_-Jackson and northern Woodruff Counties; and White, Prairie, Monroe, Arkansas, and Phillips Counties (Schrader, 2015) —now indicate declines in water-level altitude. Rises in water-level altitude were also indicated in Arkansas, Ashley, eastern Clay, Cross, western Desha, Jefferson, Lincoln, St. Francis and White Counties.
The mean countywide annual difference in water-level altitude was -0.43 foot per year (ft/yr) for the entire study area, with a range from -0.87 to $0.12 \mathrm{ft} / \mathrm{yr}$ among individual counties (table 4). Mean countywide annual declines between -0.50 and $0.00 \mathrm{ft} / \mathrm{yr}$ occurred in Arkansas, Ashley, Clay, Crittenden, Drew, Jefferson, Mississippi, Monroe, Phillips, Prairie, Randolph, and Woodruff Counties. Mean county annual declines between -1.00 and $-0.50 \mathrm{ft} / \mathrm{yr}$ occurred in Chicot, Craighead, Cross, Desha, Greene, Jackson, Lawrence, Lee, Lincoln, Lonoke, Poinsett, and St. Francis Counties. Mean county annual rises occurred in Independence and White Counties.

\section{Long-Term Hydrographs}

Fourteen hydrographs were analyzed for this report, and of those, 11 indicate a decline in water-level altitude over the period of record, ranging from $0.15 \mathrm{ft} / \mathrm{yr}$ at well 03S04W03DCA16 in Arkansas County to $1.5 \mathrm{ft} / \mathrm{yr}$ at well 11N02E26AAB1 in Poinsett County (fig. 5). Wells whose data are shown in figure $5 \mathrm{~A}-\mathrm{N}$ are labeled using corresponding index letters " $A$ " through " $N$ " in plate 1 . Data from five wells in Arkansas County (fig. 5 A-E ), one well in Ashley County (fig. 5F ), one well in Craighead County (fig. 5G), three wells in Cross County (fig. $5 \mathrm{H}-\mathrm{J}$ ), and one well in Jackson, Lee, Lonoke, and Poinsett Counties (fig. 5K-N) were analyzed to assess water-level altitude rise and (or) decline in both large cones of depression. Of the five wells in Arkansas County, three within the cone of depression experienced a decline in water-level altitude. Specifically, water levels at wells 02S04W11DBB1, 03S04W03DCA16, and 04S04W02ABB1 (fig. 5A-C) declined 0.18, 0.15, and $0.29 \mathrm{ft} / \mathrm{yr}$, respectively. The declines at these three wells are representative of the continued water-level altitude decline within the cone of depression. Along the outer edge of the cone of depression, the water level rose $0.15 \mathrm{ft} / \mathrm{yr}$ in Arkansas County well 05S04W07CCC1 (fig. 5D; pl. 1). Outside the cone of depression, the water level has risen $0.58 \mathrm{ft} / \mathrm{yr}$ since 1988 in Arkansas County well 07S04W01DDD1 (fig. 5E, pl. 1). The water level in well 07S04W01DDD1 (fig. 5E) near the Arkansas River was relatively stable until about 1990, with larger fluctuations from 1990 to present (Schrader, 2010, 2015). The water level in the Arkansas River is maintained by a lock and dam system and can be a source of water for the alluvial aquifer in southern and western Arkansas County (Schrader, 2010, 2015). In Ashley County, the water level has risen $0.11 \mathrm{ft} / \mathrm{yr}$ in well 18S08W28DDD2 over the period of record (fig. 5F). 
Table 3. Summary statistics for water-level altitude differences, by county, in selected wells in the Mississippi River Valley alluvial aquifer.

[All values were calculated by subtracting the 2010 water-level altitude from the 2014 water-level altitude at each well. A negative value indicates a decline in water-level altitude between 2010 to 2014. --, data not available]

\begin{tabular}{|c|c|c|c|c|c|}
\hline County & $\begin{array}{c}\text { Minimum } \\
\text { water-level altitude } \\
\text { difference (feet) }\end{array}$ & $\begin{array}{c}\text { Maximum } \\
\text { water-level altitude } \\
\text { difference (feet) }\end{array}$ & $\begin{array}{c}\text { Median } \\
\text { water-level altitude } \\
\text { difference (feet) }\end{array}$ & $\begin{array}{c}\text { Mean } \\
\text { water-level altitude } \\
\text { difference (feet) }\end{array}$ & $\begin{array}{l}\text { Number } \\
\text { of wells }\end{array}$ \\
\hline Arkansas & -9 & 4 & -1.9 & -2.3 & 29 \\
\hline Ashley & -9 & 3 & -2.0 & -2.6 & 19 \\
\hline Chicot & -7 & 0 & -3.7 & -3.9 & 14 \\
\hline Clay & -4 & 2 & -2.4 & -1.7 & 8 \\
\hline Craighead & -10 & 3 & -3.8 & -3.6 & 30 \\
\hline Crittenden & -5 & 2 & -2.2 & -1.8 & 10 \\
\hline Cross & -5 & 2 & -3.1 & -2.3 & 14 \\
\hline Desha & -8 & 4 & -2.0 & -1.6 & 11 \\
\hline Drew & -8 & -3 & -5.5 & -5.5 & 6 \\
\hline Greene & -10 & 0 & -4.2 & -4.1 & 21 \\
\hline Independence & -2 & -1 & -1.4 & -1.6 & 3 \\
\hline Jackson & -8 & 11 & -3.7 & -2.6 & 13 \\
\hline Jefferson & -7 & 7 & -3.4 & -1.7 & 10 \\
\hline Lawrence & -4 & 1 & -3.8 & -3.1 & 6 \\
\hline Lee & -7 & 0 & -4.1 & -3.6 & 11 \\
\hline Lincoln & -10 & 2 & -5.1 & -4.4 & 12 \\
\hline Lonoke & -7 & 1 & -2.6 & -2.6 & 16 \\
\hline Mississippi & -5 & 2 & -1.6 & -1.9 & 10 \\
\hline Monroe & -9 & 3 & -3.2 & -3.4 & 23 \\
\hline Phillips & -6 & -3 & -4.2 & -4.4 & 6 \\
\hline Poinsett & -6 & 1 & -4.4 & -3.7 & 12 \\
\hline Prairie & -8 & 18 & -1.9 & 0.2 & 20 \\
\hline Pulaski & -- & -- & -- & -- & -- \\
\hline Randolph & -3 & -1 & -2.7 & -2.3 & 4 \\
\hline St. Francis & -10 & 0 & -4.4 & -4.3 & 13 \\
\hline White & -5 & 7 & -1.1 & -0.4 & 10 \\
\hline Woodruff & -7 & 0 & -2.8 & -2.8 & 14 \\
\hline
\end{tabular}


Table 4. Range, mean, and median of annual year-to-year difference in water level, by county, for wells in the Mississippi River Valley alluvial aquifer, 1990-2014.

[Annual year-to-year difference in water level for each well is calculated using linear regression; negative value indicates decline; positive value indicates rise]

\begin{tabular}{|c|c|c|c|c|}
\hline County & $\begin{array}{c}\text { Number } \\
\text { of } \\
\text { wells }\end{array}$ & $\begin{array}{c}\text { Range of annual } \\
\text { year-to-year } \\
\text { difference in } \\
\text { water level } \\
\text { (feet per year) }\end{array}$ & $\begin{array}{l}\text { Mean annual } \\
\text { year-to-year } \\
\text { difference in } \\
\text { water level } \\
\text { (feet per year) }\end{array}$ & $\begin{array}{c}\text { Median annual } \\
\text { year-to-year } \\
\text { difference in } \\
\text { water level } \\
\text { (feet per year) }\end{array}$ \\
\hline Arkansas & 23 & -0.73 to 0.69 & -0.13 & -0.18 \\
\hline Ashley & 15 & -0.84 to 0.11 & -0.43 & -0.44 \\
\hline Chicot & 6 & -1.21 to -0.18 & -0.66 & -0.55 \\
\hline Clay & 5 & -0.77 to -0.01 & -0.31 & -0.33 \\
\hline Craighead & 17 & -1.50 to -0.01 & -0.59 & -0.51 \\
\hline Crittenden & 12 & -0.77 to -0.01 & -0.43 & -0.38 \\
\hline Cross & 26 & -1.57 to -0.07 & -0.87 & -0.91 \\
\hline Desha & 12 & -1.28 to -0.51 & -0.82 & -0.84 \\
\hline Drew & 7 & -0.58 to -0.26 & -0.42 & -0.40 \\
\hline Greene & 9 & -1.10 to 0.00 & -0.51 & -0.44 \\
\hline Independence & 2 & -0.02 to 0.26 & 0.12 & 0.12 \\
\hline Jackson & 9 & -0.80 to -0.26 & -0.56 & -0.62 \\
\hline Jefferson & 5 & -0.44 to -0.07 & -0.32 & -0.40 \\
\hline Lawrence & 5 & -0.88 to -0.04 & -0.58 & -0.77 \\
\hline Lee & 5 & -0.91 to -0.55 & -0.70 & -0.69 \\
\hline Lincoln & 10 & -1.21 to -0.29 & -0.69 & -0.77 \\
\hline Lonoke & 17 & -1.42 to 0.00 & -0.67 & -0.69 \\
\hline Mississippi & 8 & -0.37 to 0.07 & -0.04 & 0.02 \\
\hline Monroe & 18 & -0.84 to 0.11 & -0.30 & -0.27 \\
\hline Phillips & 7 & -0.40 to -0.01 & -0.20 & -0.15 \\
\hline Poinsett & 7 & -1.50 to -0.01 & -0.72 & -0.84 \\
\hline Prairie & 8 & -0.62 to 0.37 & -0.17 & -0.16 \\
\hline Randolph & 1 & -0.26 to -0.26 & -0.26 & -0.26 \\
\hline St. Francis & 6 & -1.02 to -0.18 & -0.71 & -0.79 \\
\hline White & 7 & -0.37 to 0.51 & 0.02 & 0.07 \\
\hline Woodruff & 16 & -0.95 to 0.04 & -0.20 & -0.04 \\
\hline
\end{tabular}



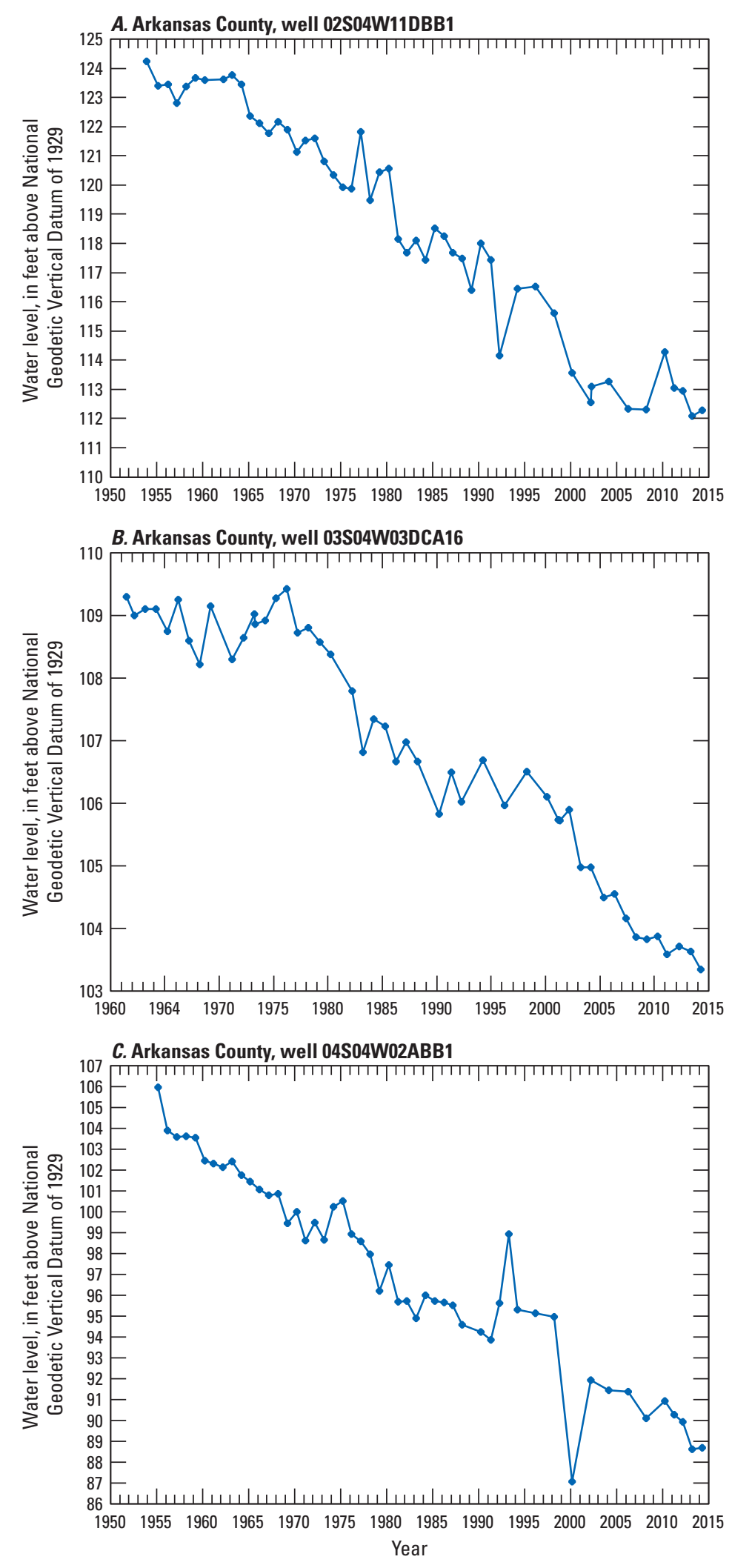

Figure 5. Water-level altitude hydrographs for selected wells completed in the Mississippi River Valley alluvial aquifer in Arkansas. 

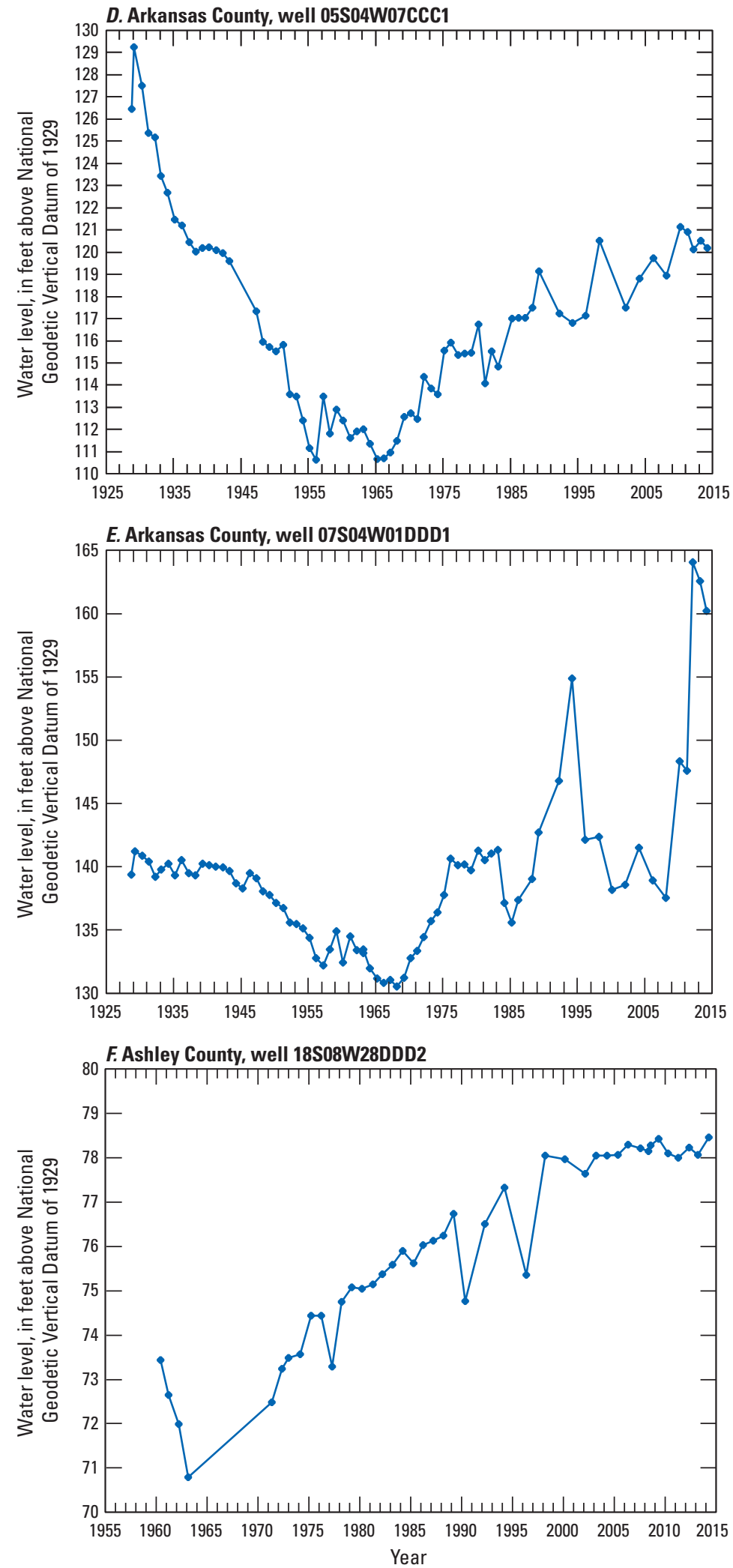

Figure 5. Water-level altitude hydrographs for selected wells completed in the Mississippi River Valley alluvial aquifer in Arkansas.-Continued 

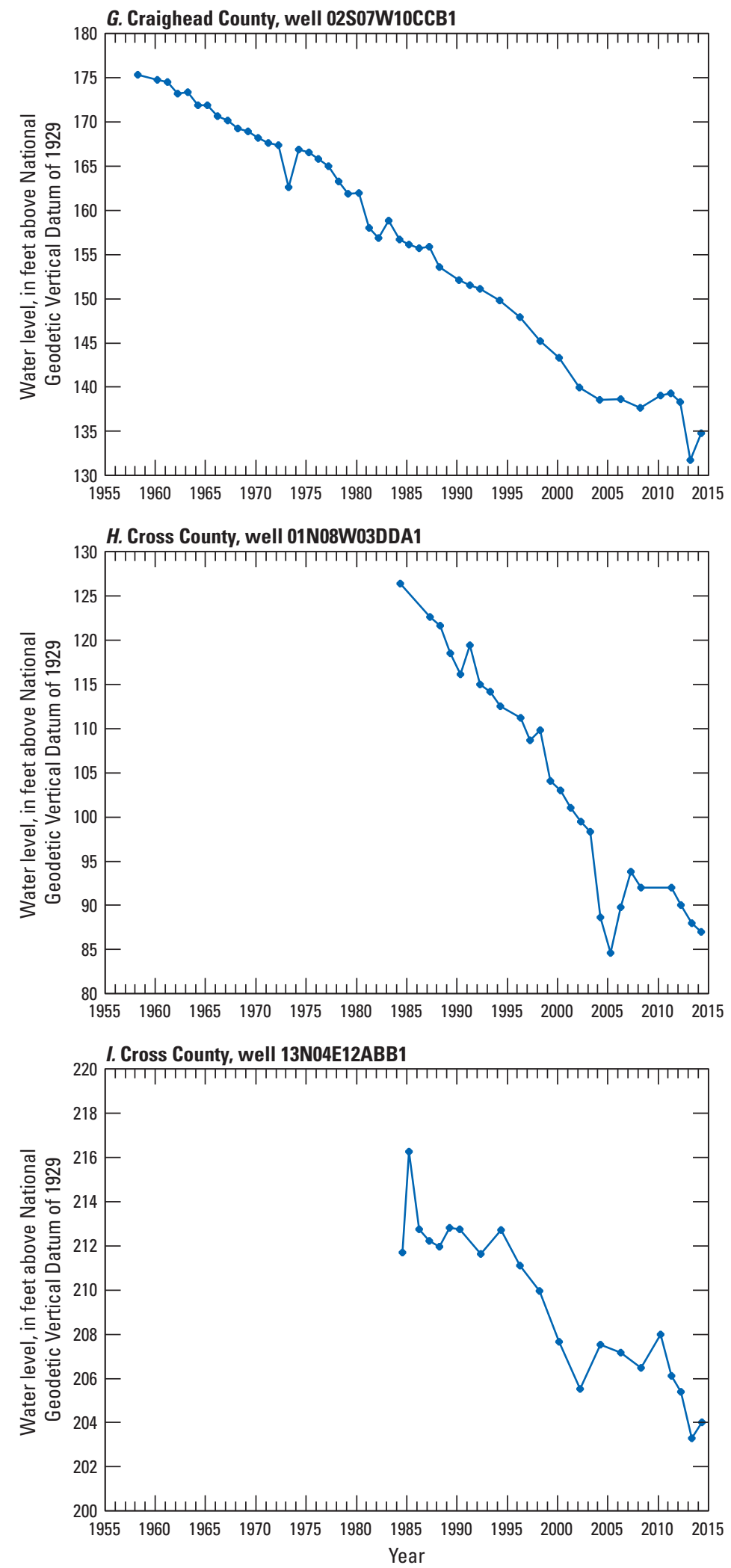

Figure 5. Water-level altitude hydrographs for selected wells completed in the Mississippi River Valley alluvial aquifer in Arkansas.-Continued 

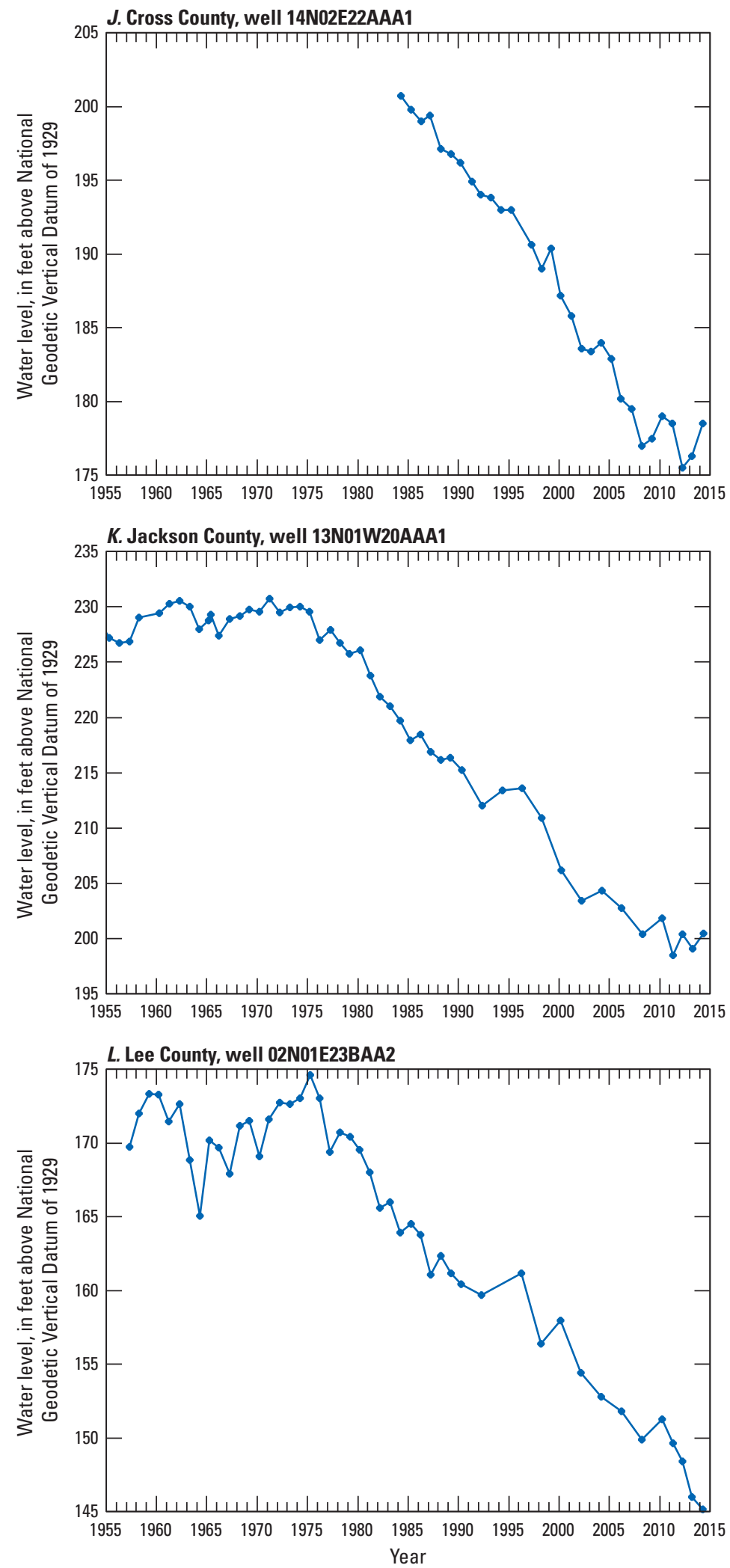

Figure 5. Water-level altitude hydrographs for selected wells completed in the Mississippi River Valley alluvial aquifer in Arkansas.-Continued 

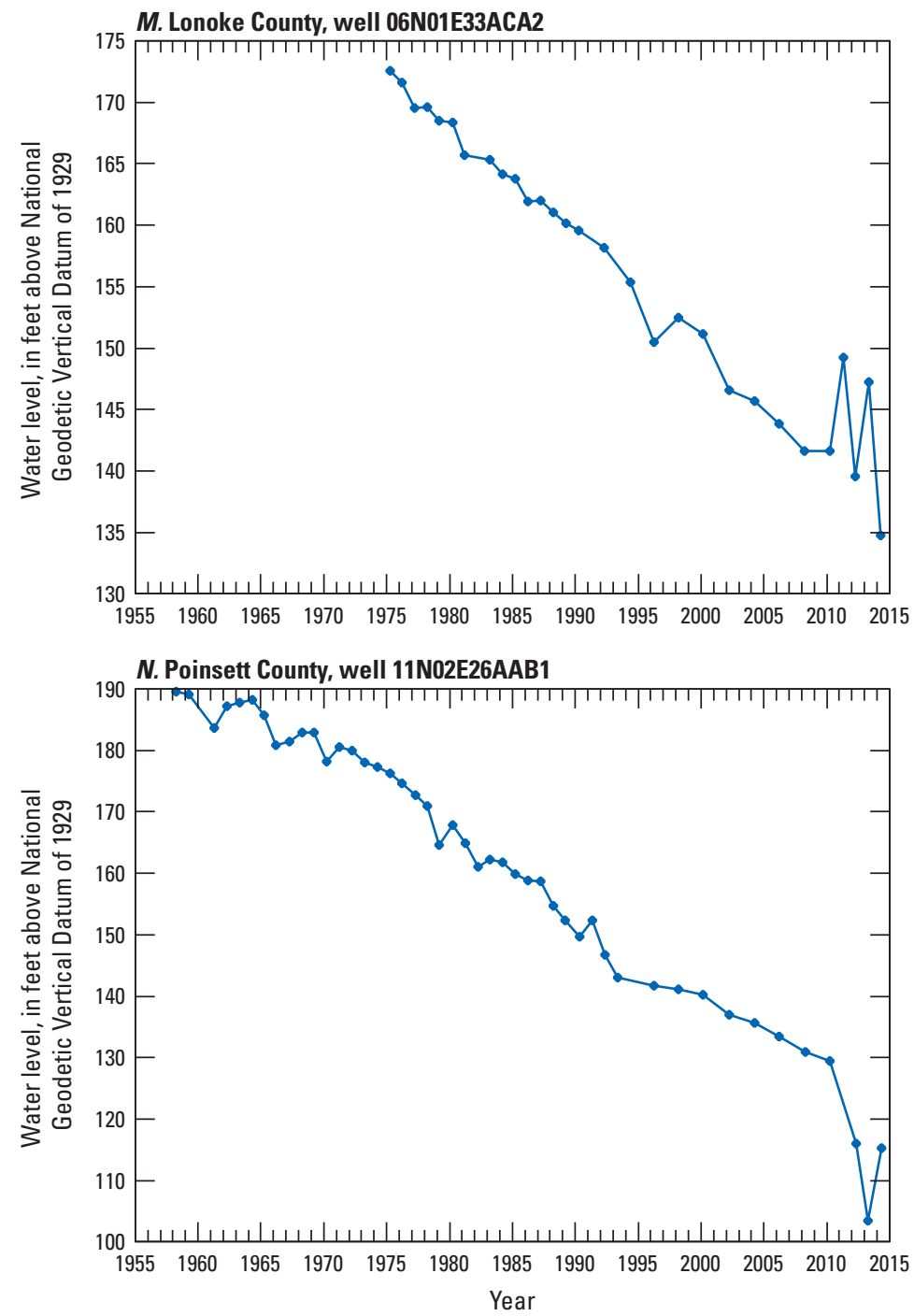

Figure 5. Water-level altitude hydrographs for selected wells completed in the Mississippi River Valley alluvial aquifer in Arkansas.-Continued 
In Craighead County, the water-level altitude declined approximately $0.73 \mathrm{ft} / \mathrm{yr}$ since 1988 in well 02S07W10CCB1 (fig. 5G , pl. 1). The water level in this well has continuously declined since the measurement of water levels began over 55 years ago. In Cross County, the annual groundwater level declined $1.42 \mathrm{ft} / \mathrm{yr}$ in well 01N08W03DDA1 (fig. 5H ), which is located within the northwestern part of the southern cone of depression. This decline is approximately twice the rate of decline in well 02S07W10CCB1 in Craighead County and is an indication that the cone of depression is continuing to increase in depth, which suggests that water withdrawal within the area of this cone of depression has not decreased. Declines in water-level altitudes in neighboring counties are further evidence of the deepening of the depression centered in Arkansas, Lonoke, and Prairie Counties (Schrader, 2015).

In Cross County, two wells were analyzed to assess the effects of groundwater withdrawals near Crowleys Ridge. East of Crowleys Ridge, the annual water-level altitude decline is $0.33 \mathrm{ft} / \mathrm{yr}$ at the Cross County well 13N04E12ABB1 (fig. $5 \mathrm{I}$ ). West of Crowleys Ridge, the annual water-level altitude decline is approximately $0.91 \mathrm{ft} / \mathrm{yr}$ at Cross County well 14N02E22AAA1 (fig. 5J ). The three-fold difference in decline between these locations is a result of increased groundwater withdrawals west of Crowleys Ridge, which can account for the continued decline seen in the northern cone of depression. In Jackson County, the annual water-level altitude decline is about $0.69 \mathrm{ft} / \mathrm{yr}$ in well 13N01W20AAA1 (fig. 5K , pl. 1). Long-term declines in this outlying well suggest that the depression in the northwestern part of the study area may expand to the west with continued drawdown.

Hydrographs for Lee County well 02N01E23BAA2 (fig. $5 \mathrm{~L}$ ), which is located in the southwestern part of the northern cone of depression, and Lonoke County well 06N01E33ACA2 (fig. 5M ), indicated water-level altitude declines of 0.66 and $0.77 \mathrm{ft} / \mathrm{yr}$, respectively. The water-level altitude is also declining in Poinsett County, as indicated by the hydrograph for well 11N02E26AAB1 (fig. 5N) (1.5 ft/yr). The rate of decline in Poinsette County well 11N02E26AAB1 is approximately twice the rate of water-level altitude declines in Lee County well 02N01E23BAA2 (fig. 5L) and Lonoke County well 06N01E33ACA2 (fig. 5M ).

\section{Chloride and Bromide Concentrations}

Chloride concentrations in the alluvial aquifer ranged from a maximum of 1,090 milligrams per liter $(\mathrm{mg} / \mathrm{L})$ in Chicot County to a minimum of $2.21 \mathrm{mg} / \mathrm{L}$ in Crittenden County (Rodgers, 2020). Rice and soybean, two major crops in eastern Arkansas, are sensitive to chloride concentrations. Tacker and others (1994) noted that groundwater containing chloride concentrations in excess of $100 \mathrm{mg} / \mathrm{L}$ is not recommended for irrigation of rice. Fourteen of the 144 wells contained chloride concentrations above $100 \mathrm{mg} / \mathrm{L}$ (Rodgers, 2020). High chloride levels at wells in this study correspond with Area I identified in Kresse and Clark (2008) and are attributed to dissolved solids, low permeability, backwater swamp deposits and the lithostratigraphy of the area. In addition, high chloride levels south of the Arkansas River (Jefferson, Lincoln, and Desha Counties) have been identified in literature (Klein and others, 1950; Onellion and Criner, 1955; Bedinger and Jeffery, 1964; Broom and Reed, 1973; Kresse and Fazio, 2002; and Kresse and Clark, 2008). Bromide concentrations ranged from a maximum of $4.71 \mathrm{mg} / \mathrm{L}$ to a minimum of $0.03 \mathrm{mg} / \mathrm{L}$, both in Chicot County (Rodgers, 2020).

Chloride/bromide ratios ranged from 40.9 in Crittendon County to 463 in Clay County (table 5). The range in ratios suggests varying conditions within the alluvial aquifer. A high chloride/bromide ratio can be useful in tracing the origin, movement, and history of groundwater as well as determining sources of pollution (Davis and others, 1998). Davis and others (1998) found that higher ratios suggest the addition of chloride from sources other than the aquifer such as the movement of saltwater into the aquifer. The ratio for most of the sampled wells was between 101 to 200 (fig. 6, pl. 3) which is indicative of shallow groundwater (Davis and others, 1998). Other possible sources of water to the alluvial aquifer include atmospheric deposition/precipitation (0 to 100 chloride/ bromide ratio), brine formations (201 to 300 chloride/ bromide ratio), and human influence such as domestic sewage, wastewater treatment, and pesticides (chloride/bromide ratios greater than 300) (Alcalá and Custodio, 2008; Davis and others, 1998). There does not appear to be any correlation between high chloride/bromide ratios and areas of decreasing water levels in the alluvial aquifer (pl. 3). 
Table 5. Summary statistics for chloride/bromide ratios by county in samples from selected wells in the Mississippi River Valley alluvial aquifer, 2014.

\begin{tabular}{|c|c|c|c|c|c|}
\hline County & $\begin{array}{c}\text { Minimum } \\
\text { chloride/bromide } \\
\text { ratio }\end{array}$ & $\begin{array}{c}\text { Maximum } \\
\text { chloride/bromide } \\
\text { ratio }\end{array}$ & $\begin{array}{c}\text { Median } \\
\text { chloride/bromide } \\
\text { ratio }\end{array}$ & $\begin{array}{c}\text { Mean } \\
\text { chloride/bromide } \\
\text { ratio }\end{array}$ & $\begin{array}{l}\text { Number } \\
\text { of wells }\end{array}$ \\
\hline Arkansas & 121.0 & 387.0 & 262.0 & 257.2 & 6 \\
\hline Ashley & 208.0 & 300.0 & 224.0 & 244.0 & 3 \\
\hline Chicot & 98.0 & 231.0 & 166.5 & 173.0 & 6 \\
\hline Clay & 115.0 & 463.0 & 212.0 & 252.0 & 5 \\
\hline Craighead & 128.0 & 223.0 & 198.5 & 190.5 & 6 \\
\hline Crittenden & 40.9 & 237.0 & 80.1 & 98.4 & 6 \\
\hline Cross & 95.8 & 209.0 & 123.0 & 137.1 & 5 \\
\hline Desha & 138.0 & 354.0 & 270.0 & 260.9 & 7 \\
\hline Drew & 113.0 & 196.0 & 166.0 & 160.3 & 4 \\
\hline Greene & 112.0 & 212.0 & 122.5 & 136.3 & 6 \\
\hline Independence & 90.6 & 98.6 & 94.6 & 94.6 & 2 \\
\hline Jackson & 118.0 & 145.0 & 134.0 & 132.3 & 3 \\
\hline Jefferson & 152.0 & 403.0 & 212.0 & 243.3 & 7 \\
\hline Lawrence & 98.7 & 163.0 & 146.5 & 138.7 & 4 \\
\hline Lee & 95.3 & 177.0 & 110.0 & 121.9 & 10 \\
\hline Lincoln & 134.0 & 402.0 & 240.5 & 260.9 & 8 \\
\hline Lonoke & 130.0 & 285.0 & 170.0 & 183.8 & 5 \\
\hline Mississippi & 51.2 & 209.0 & 74.0 & 104.8 & 6 \\
\hline Monroe & 117.0 & 251.0 & 150.0 & 172.1 & 7 \\
\hline Phillips & 82.3 & 138.0 & 109.0 & 112.8 & 8 \\
\hline Poinsett & 96.0 & 263.0 & 142.0 & 157.9 & 6 \\
\hline Prairie & 82.9 & 134.0 & 111.0 & 111.0 & 7 \\
\hline Pulaski & 81.2 & 105.0 & 93.1 & 93.1 & 2 \\
\hline Randolph & 167.0 & 253.0 & 198.0 & 206.0 & 3 \\
\hline St. Francis & 92.1 & 108.0 & 99.7 & 99.9 & 4 \\
\hline White & 94.9 & 162.0 & 127.0 & 127.7 & 4 \\
\hline Woodruff & 135.0 & 195.0 & 147.5 & 156.3 & 4 \\
\hline
\end{tabular}




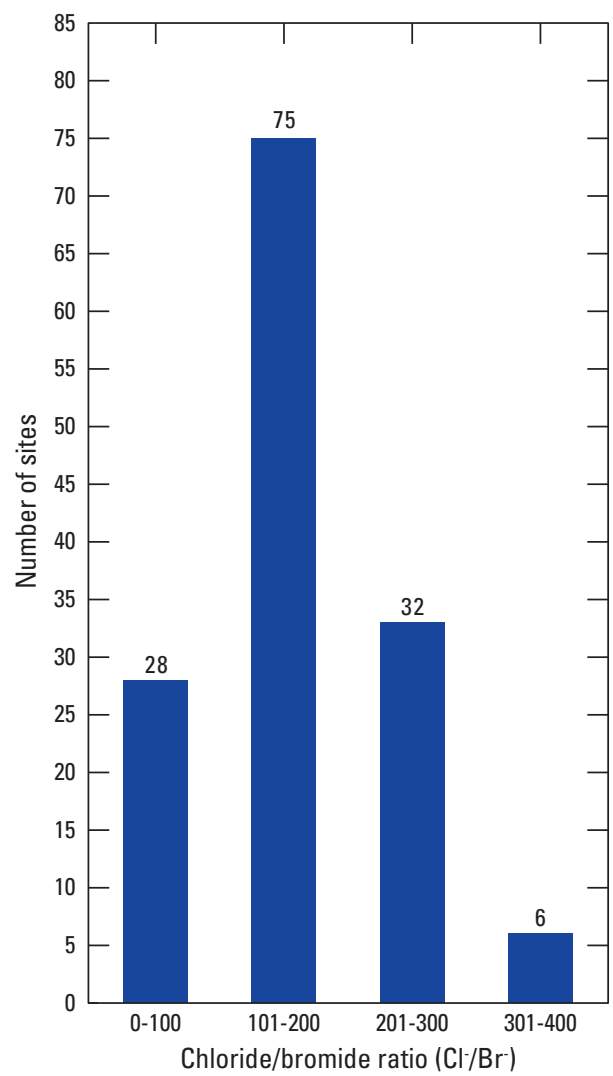

Figure 6. Distribution of chloride/bromide ratios in samples from the Mississippi River Valley alluvial aquifer in Arkansas, 2014.
Water levels varied substantially across the study area. Areas having the lowest water levels (that is, cones of depression) have not increased in size since 2012. Waterlevel altitude difference analysis throughout the study area found that water-level altitudes had declined in approximately 84 percent of wells completed in the alluvial aquifer.

In 2012, three locations in the alluvial aquifer study area indicated rises in water-level altitude. Conversely, this study determined that the water-level altitude had declined in wells in these same three areas. Analysis of long-term hydrographs indicated a continued decline in water-level altitude. Fourteen hydrographs were analyzed, and 11 wells showed declines in water-level altitude. The mean annual water-level altitude declined in all but two counties in the study area, and there was a continued decrease in water-level altitude in the cones of depression.

Analysis of chloride and bromide concentrations in the study area indicated the presence of elevated chloride/ bromide ratios at several locations. Elevated concentrations of chloride and bromide (and hence, their ratios) may be due to sources other than those naturally occurring within the aquifer, such as the movement of saltwater into the aquifer from brine formations and human influence. Most of the wells contained chloride concentrations less than 100 milligrams per liter, which is suitable for irrigation of soybeans and rice. In addition, the majority of the wells contained a chloride/ bromide ratio less than or equal to 200, which is indicative of atmospheric deposition/precipitation and shallow groundwater.

\section{References Cited}

\section{Summary and Conclusions}

Water-level measurements and water-quality samples were collected by the U.S. Geological Survey in cooperation with the Arkansas Geological Survey, the Arkansas Natural Resources Commission, and the Natural Resource Conservation Service. The collected data and samples were used to analyze the potentiometric surface, difference in water-level altitude between 2010 and 2014, long-term groundwater trends, and chloride/bromide concentrations in the Mississippi River Valley alluvial aquifer in 2014. The potentiometric-surface map indicates the continued decline in water levels between 2010 and 2014 in 10 areas of the alluvial plain, which in turn indicates that water usage has not changed substantially.

Groundwater flow in the alluvial aquifer is affected by cones of depression in the potentiometric surface and areas of decreased groundwater levels. The depressions alter the regional groundwater flow toward the areas of increased groundwater use. Flow direction varies throughout the study area and is affected by natural boundaries, such as Crowleys Ridge. The flow of groundwater away from rivers indicates that the rivers are losing water to the aquifer in some locations.
Ackerman, D.J., 1996, Hydrology of the Mississippi River Valley alluvial aquifer, south-central United States: U.S. Geological Survey Professional Paper 1416-D, 56 p., accessed November 2015 at https://pubs.er.usgs.gov/ publication/pp1416D.

Alcalá, F.J., and Custodio, E., 2008, Using the $\mathrm{Cl} / \mathrm{Br}$ ratio as a trace to identify the origin of salinity in aquifers in Spain and Portugal: Journal of Hydrology, v. 359, p. 189-207, accessed March 2016 at http://www.eeza. csic.es/Documentos/Publicaciones/Alcal\%E1_\%26_ Custodio_2008(Journal_Hyd).pdf.

Arthur, J.K., and Taylor, R.E., 1998, Ground-water flow analysis of the Mississippi embayment aquifer system, South-Central United States: U.S. Geological Survey Professional Paper 1416-I, 148 p. accessed November 2015 at https://pubs.er.usgs.gov/publication/ pp1416I?currow=975.

Bedinger, M.S., and Jeffery, H.G., 1964, Ground water in the Lower Arkansas River Valley, Arkansas: U.S. Geological Survey Water-Supply Paper 1669-V, 17 p. 
Bodansky, E., Gribov, A., and Pilouk, M., 2002, Smoothing and compression of lines obtained by raster-to-vector conversion: Heidelberg, Germany, Springer Publishing, Lecture Notes in Computer Science, v. 2390, p. 256-265, accessed March 2013 at http://link.springer.com/chapter/10. 1007\%2F3-540-45868-9_22.

Boswell, E.H., Cushing, E.M., and Hosman, R.L., 1968, Quaternary aquifers in the Mississippi embayment, with a discussion of Quality of the water, by Jeffery, H.G.: U.S. Geological Survey Professional Paper 448-E, 15 p. [Also available at https://pubs.usgs.gov/pp/0448e/report.pdf.]

Broom, M.E., and Reed, J.E., 1973, Hydrology of the Bayou Bartholomew alluvial aquifer-stream system, Arkansas: U.S. Geological Survey Open-File Report 73-34, 91 p.

Clark, B.R., Hart, R.M., and Gurdak, J.J., 2011, Groundwater availability of the Mississippi embayment: U.S. Geological Survey Professional Paper 1785, 62 p. [Also available at https://pubs.usgs.gov/pp/1785/.]

Cunningham, W.L., and Schalk, C.W., comps., 2011, Groundwater technical procedures of the U.S. Geological Survey: U.S. Geological Survey Techniques and Methods, book 1, chap. A1, 151 p., accessed May 2013 at https:// pubs.usgs.gov/tm/1a1/.

Cushing, E.M., Boswell, B.H., and Hosman, R.L., 1964, General geology of the Mississippi embayment: U.S. Geological Survey Professional Paper 448-B, 28 p. [Also available at https://pubs.usgs.gov/pp/0448b/report.pdf.]

Davis, S.N., Whittemore, D.O., and Fabryka-Martin, J., 1998, Uses of chloride/bromide ratios in studies of potable water: Ground Water, v. 36, no. 2., p. 338-350, accessed June 2015 at https://onlinelibrary.wiley.com/doi/ abs/10.1111/j.1745-6584.1998.tb01099.x.

Esri, 2011, ArcGIS desktop-Release 10: Redlands, California, Environmental Systems Research Institute.

Evenson, E.J., Orndorff, R.C., Blome, C.D., Böhlke, J.K., Hershberger, P.K., Langenheim, V.E., McCabe, G.J., Morlock, S.E., Reeves, H.W., Verdin, J.P., Weyers, H.S., and Wood, T.M., 2013, U.S. Geological Survey water science strategy_Observing, understanding, predicting, and delivering water science to the Nation: U.S. Geological Survey Circular 1383-G, 49 p., accessed March 2015 at https://pubs.usgs.gov/circ/1383g/circ1383-G.pdf.

Fenneman, N.M., 1938, Physiography of eastern United States: New York, McGraw-Hill, 689 p.

Fenneman, N.M., and Johnson, D.W., 1946, Physiographic divisions of the conterminous U.S.: U.S. Geological Survey map, scale 1:7,000,000, accessed September 22, 2015, at http://water.usgs.gov/GIS/metadata/usgswrd/XML/physio. $\mathrm{xml}$.
Fishman, M.J., and Friedman, L.C., 1989, Methods for determination of inorganic substances in water and fluvial sediments: U.S. Geological Survey Techniques of Water-Resources Investigations, book 5, chap. A1, 545 p., accessed March 2015 at https://pubs.er.usgs.gov/ publication/twri05A1.

Halberg, H.N., 1972, Use of water in Arkansas, 1970: Arkansas Geological Commission Water Resources Summary No. 7, 17 p. [Also available at https://www. geology.arkansas.gov/docs/pdf/publication/water_ summaries/Water-Resources-Summary-7.pdf.]

Halberg, H.N., 1977, Use of water in Arkansas, 1975: Arkansas Geological Commission Water Resources Summary No. 9, 28 p. [Also available at https://pubs. er.usgs.gov/publication/70047770.]

Halberg, H.N., and Stephens, J.W., 1966, Use of water in Arkansas, 1965: Arkansas Geological Commission Water Resources Summary No. 5, 12 p. [Also available at https:// www.geology.arkansas.gov/docs/pdf/publication/water_ summaries/Water-Resources-Summary-5.pdf.]

Hart, R.M., Clark, B.R., and Bolyard, S.E., 2008, Digital surfaces and thicknesses of selected hydrogeologic units within the Mississippi Embayment Regional Aquifer Study (MERAS): U.S. Geological Survey Scientific Investigations Report 2008-5098, 33 p., accessed May 2016 at https:// pubs.er.usgs.gov/publication/sir20085098.

Helsel, D.R., and Hirsch, R.M., 2002, Statistical methods in water resources: U.S. Geological Survey Techniques of Water Resources Investigations, book 4, chap. A3, 522 p., accessed March 2015, at https://pubs.usgs.gov/twri/ twri4a3/.

Holland, T.W., 1987, Use of water in Arkansas, 1985: Arkansas Geological Commission Water Resources Summary No. 14, 30 p. [Also available at https://www. geology.arkansas.gov/docs/pdf/publication/water_ summaries/Water-Resources-Summary-16.pdf.]

Holland, T.W., 1993, Use of water in Arkansas, 1990: U.S. Geological Survey Open-File Report 93-48, 9 p. [Also available at https://pubs.er.usgs.gov/publication/ofr9348.]

Holland, T.W., 1999, Water use in Arkansas, 1995: U.S. Geological Survey Open-File Report 99-188, 1 sheet. [Also available at https://pubs.er.usgs.gov/publication/ofr99188.]

Holland, T.W., 2004, Estimated water use in Arkansas, 2000: U.S. Geological Survey Scientific Investigations Report 2004-5230, 31 p. [Also available at https://pubs.er.usgs. gov/publication/sir20045230.]

Holland, T.W., 2007, Water use in Arkansas, 2005: U.S. Geological Survey Scientific Investigations Report 2007-5241, 31 p. [Also available at https://pubs.usgs.gov/ sir/2007/5241/.] 
Holland, T.W., and Ludwig, A.H., 1981, Use of water in Arkansas, 1980: Arkansas Geological Commission Water Resources Summary No. 14, 30 p. [Also available at https:// www.geology.arkansas.gov/docs/pdf/publication/water_ summaries/WRS-14-Use-of-Water-in-Arkansas-1980.pdf.

Joseph, R.L., 1999, Status of water levels and selected waterquality conditions in the Mississippi River Valley alluvial aquifer in eastern Arkansas, 1998: U.S. Geological Survey Water-Resources Investigations Report 99-4035, 54 p. [Also available at https://doi.org/10.3133/wri994035.]

Klein, H., Baker, R.C., and Billingsley, G.A., 1950, Groundwater resources of Jefferson County, Arkansas: Arkansas University, Institute of Science and Technology Research Series 19, $44 \mathrm{p}$.

Kresse, T.M., and Clark, B.R., 2008, Occurrence, distribution, sources, and trends of elevated chloride concentrations in the Mississippi River Valley alluvial aquifer in southeastern Arkansas: U.S. Geological Survey Scientific Investigations Report 2008-5193, 34 p.

Kresse, T.M., and Fazio, J.A., 2002, Pesticides, water quality, and geochemical evolution of ground water in the alluvial aquifer, Bayou Bartholomew Basin, Arkansas: Arkansas Department of Environmental Quality, Water Quality Report WQ02-05-1, 111 p.

Kresse, T.M., Hays, P.D., Merriman, K.R., Gillip, J.A., Fugitt, D.T., Spellman, J.L., Nottmeier, A.M., Westerman, D.A., Blackstock, J.M., and Battreal, J.L., 2014, Aquifers of Arkansas-Protection, management, and hydrologic and geochemical characteristics of groundwater resources in Arkansas: U.S. Geological Survey Scientific Investigations Report 2014-5149, 334 p. [Also available at https://pubs. usgs.gov/sir/2014/5149/.]

Lohman, S.W., 1972, Ground-water hydraulics: U.S. Geological Survey Professional Paper 708, 70 p., accessed November 2017 at https://pubs.er.usgs.gov/publication/ pp708.

Mahon, G.L., and Poynter, D.T., 1993, Development, calibration, and testing of ground-water flow models for the Mississippi River Valley alluvial aquifer in eastern Arkansas using one-square mile cells: U.S. Geological Survey WaterResources Investigations Report 92-4106, 33 p., accessed November 2017 at https://pubs.usgs.gov/wri/1992/4106/ report.pdf.

Onellion, F.E., and Criner, J.H., Jr., 1955, Ground-water resources of Chicot County, Arkansas: Arkansas Geology and Conservation Commission Water Resources Circular 3, $27 \mathrm{p}$.
Pugh, A.L., and Holland, T.W., 2015, Estimated water use in Arkansas, 2010: U.S. Geological Survey Scientific Investigations Report 2015-5062, 33 p., accessed September 26, 2015, at http://dx.doi.org/10.3133/ sir20155062.

Pugh, A.L., Westerfield, P.W., and Poynter, D.T., 1997, Thickness of the Mississippi River Valley alluvial aquifer in eastern Arkansas: U.S. Geological Survey Water-Resources Investigations Report 97-4049, 1 plate. [Also available at https://pubs.er.usgs.gov/publication/wri974049.]

Reed, T.B., 2004, Status of water levels and selected waterquality conditions in the Mississippi River Valley alluvial aquifer in eastern Arkansas, 2002: U.S. Geological Survey Scientific Investigations Report 2004-5129, 53 p. [Also available at https://pubs.usgs.gov/sir/2004/5129/.]

Rodgers, K.D., 2020, Water-level data, selected water-quality data, and the potentiometric dataset for the Mississippi River Valley alluvial aquifer in eastern Arkansas, spring 2014: U.S. Geological Survey data release, https://doi. org/10.5066/F757197T.

Saucier, R.T., 1994, Geomorphology and Quaternary geologic history of the Lower Mississippi Valley, volume I: U.S. Army Corps of Engineers, Waterways Experiment Station, Vicksburg, Miss., 400 p.

Schrader, T.P., 2008, Water levels and selected water-quality conditions in the Mississippi River Valley alluvial aquifer in eastern Arkansas, 2006: U.S. Geological Survey Scientific Investigations Report 2008-5092, 72 p. [Also available at https://pubs.usgs.gov/sir/2008/5092/.]

Schrader, T.P., 2010, Water levels and selected water-quality conditions in the Mississippi River Valley alluvial aquifer in eastern Arkansas, 2008: U.S. Geological Survey Scientific Investigations Report 2010-5140, 71 p. [Also available at https://pubs.usgs.gov/sir/2010/5140/.]

Schrader, T.P., 2015, Water levels and selected water-quality conditions in the Mississippi River Valley alluvial aquifer in eastern Arkansas, 2012: U.S. Geological Survey Scientific Investigations Report 2015-5059, 70 p. [Also available at https://pubs.usgs.gov/sir/2015/5059/.]

Tacker, P., Langston, J., Ferguson, J., and Vories, E., 1994, Water management, in Helms R.S., ed., Rice Production Handbook: University of Arkansas Cooperative Extension Service MP 192, p. 55-63.

U.S. Geological Survey, variously dated, National field manual for the collection of water-quality data: U.S. Geological Survey Techniques of Water-Resources Investigations, book 9, chaps. A1-A9. [Also available at http://pubs.water. usgs.gov/twri9A.] 
U.S. Geological Survey [USGS], 2016, USGS water data for the nation: U.S. Geological Survey National Water Information System database, accessed November 2017 at https://doi.org/10.5066/F7P55KJN.
Williamson, A.K., Grubb, H.F., and Weiss, J.S., 1990, Groundwater flow in the Gulf Coast aquifer systems, south-central United States-A preliminary analysis: U.S. Geological Survey Water-Resources Investigations Report 89-4071, 124 p., accessed March 2015 at https://pubs.usgs. gov/wri/1989/4071/report.pdf.

For more information about this publication, contact

Lower Mississippi Gulf Water Science Center

640 Grassmere Park, Suite 100

Nashville, TN 37211

For additional information visit

https://www.usgs.gov/centers/lmg-water

Publishing support provided by

Lafayette Publishing Service Center 


\section{$\frac{\mathbb{2}}{3}$}

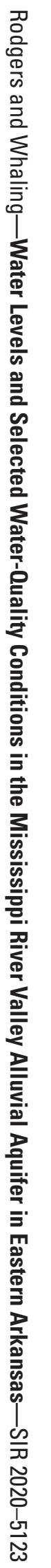

